\title{
Is the German Academic Profession on Metrification Autopilot? A Study of 25 Years of Publication Outputs
}

Christian Schneijderberg*, Lars Müller and Nicolai Götze

International Centre for Higher Education Research, University of Kassel, Moenchebergstr. 17, 34109 Kassel, Germany.

* Corresponding author: schneijderberg@incher.uni-kassel.de

\section{ORCID-IDs:}

Christian Schneijderberg: https://orcid.org/0000-0003-3240-9487

Lars Müller: https://orcid.org/0000-0003-3811-0144

Nicolai Götze: https://orcid.org/0000-0002-0519-0232

\begin{abstract}
Given their constitutionally guaranteed academic freedom, German academics are not forced by law to metrify their research outputs, but they do still practice metrification - one could say on autopilot. The metrification autopilot mode captures the voluntary commitment of a substantial part of the German academic profession to socio-calculative valuation, evaluation and valorization practices in the governance and control of higher education institutions (HEI), of disciplines and at the individual level. The effects of the metrification autopilot, in terms of auto-metrification in individual academics' publication behavior, are studied empirically using three surveys (1992, 2007 and 2018). On the individual level, the metrification autopilot is observed as a trend among all full professors. Among non-full professors, the most metrified publication outputs are produced by academics who have been in their positions for more than 13 years. Accordingly, socialization into metrified status/reputation-seeking and status/reputation-keeping academic culture seems to take about 12 years. On the organizational level, we observe the metrification autopilot trend on the basis of the correlation between journal articles and HEls' policy of strong metrified performance recognition. On the discipline level, the metrification autopilot trend is observable in the way that humanities and social sciences scholars adapt to the peer-reviewed journal publication paradigm of the natural sciences, which is a key driver for transforming science and HEls into a "socio-calculative environment" (Vormbusch 2012) of valuation, evaluation and valorization.
\end{abstract}


Keywords: Academic profession; Germany; Higher education and science policy;

Metrification; Publication outputs; Reputation

\section{Article Highlights}

- Contextual analysis of individual, organizational and discipline level processes of auto-metrification in the academic profession in Germany.

- Metrified performance recognition (MPR) as status seeking and status keeping in the German academic profession.

- Connects theories on the academic profession with organizing metrification and quantification, and evaluation, valuation and valorization research.

\section{MSC classifications:}

$62 H x x ; 62 A x x ; 91 C x x$

\section{JEL classifications:}

D73; I23; I28; 035; 038

Acknowledgements: For their feedback on different drafts of the manuscript, the authors would like to extend sincere thanks to Lutz Bornmann, Jochen Gläser, Anne K. Krüger, Soo Jeung Lee, Christiane Rittgerott, Christian J. Schmid, Isabel Steinhardt and the unknown reviewer.

Funding: This research was funded by the German Federal Ministry of Education and Research (Bundesministerium für Bildung und Forschung; grant number M522200).

Conflict of Interest: The authors declare that they have no conflict of interest. 


\section{Introduction}

Recognition of, feedback from and evaluation by other academics, all inherent in peer review, is essential to scientific development and knowledge production. In the context of various megatrends, such as the rise of a global "knowledge economy" in higher education (Ollsen and Peters 2005), an increasing "academic capitalism" (Slaughter and Leslie 1997) and "managerialism" (Marginson and Conside 2000) in higher education, academics' individual struggles for reputation have been heightened by global competition between higher education institutions (HEls) and national higher education systems. Following the New Public Management "doctrine" (Power 1999, p. 98) as adapted to higher education and science governance, several countries have become "strong evaluation states" (Whitley 2007, p. 9), for example Australia (e.g., Butler 2003a, 2003b; Marginson 2003; Woelert and McKenzie 2018), the United Kingdom (e.g., Moed 2008; Wooding et al. 2015), South Korea (e.g., Choung and Hwang 2013; Shin et al. 2009; Shin and Lee 2015) and other East Asian countries (e.g., Lyu et al. 2017; Park et al. 2016).

In comparison to South Korea and the UK, German academics are not forced by law to metrify their research outputs, but nevertheless do still practice metrification (Schimank 2010) - one could say on autopilot. ${ }^{1}$ An autopilot might be best known from aviation. The autopilot operates the aircraft at cruising altitude. Adapting the aviation analogy to the academic profession, the metrification autopilot is a metrics-oriented publication practice of academics that is based on tacit, "embodied knowledge" (Bourdieu 1995) or "bio-politics" (Foucault 2008, 2010). The term autopilot does not imply that all academics comply or that the metrical thing evolves automatically. The term autopilot acknowledges the implicit and explicit "reactivity" (Espeland and Sauder 2007) of individuals to indicators as "bearers of specific political concepts, normative scripts, economic interests or collective constructions/interpretations" (Mau 2018, p. 261, authors' translation) of social reality. ${ }^{2}$ Metrification is the expression of commensuration: "Commensuration is characterized by the transformation of qualities into quantities that share a metric, a process that is fundamental to measurement. [...]. Commensuration shapes what we pay attention to, which things are connected to other things, and how we express sameness and difference" (Espeland and Sauder 2007, p. 16). The metrification of qualities, such as creative ideas explained in academic publications (Karpik

\footnotetext{
1 The Latin prefix 'auto' is equal to the English term 'self'.

${ }^{2}$ Evidence of reactivity as part of social comparative behavioral control (Festinger 1954) in the academic profession has been generated in a neurological experiment conducted by Paulus et al. (2015) which investigated academics as status seekers. Using magnetic resonance imaging they provide insights into the brain response of academics from the field of neuroscience in anticipation of publishing in a journal. The response in the parts of the brain associated with reward, and also happiness and addiction, increased in correlation with the increase in the journal's impact factor. Paulus et al. (2015) conclude that academics have incorporated publications in high impact journals, the dominant reward principle of the scientific community, into their personal reward system.
} 
2010), constructs the "socio-calculative environment" (Vormbusch 2012, p. 206; authors' translation) of valuation, which is expressed and assured by evaluation and valorization processes (Vatin 2013).

The goal of this study is to empirically observe the effects of the metrification autopilot in terms of auto-metrification in the individual behavior of academics. Since the performance-related evolution of auto-metrification can be well observed by focusing on publication outputs (e.g., Gralka et al. 2019), this study will empirically answer the research question: Can we observe auto-piloted metrification in the German academic profession by looking at publication outputs over the course of the last 25 years (1992 - 2007 - 2018)? To answer our research question, we analyze changes in individual publication outputs on three levels: the system level (differences related to academic disciplines), the organizational level (differences related to $\mathrm{HEI}$ policies) and the individual level (differences related to academic rank and career aspirations). Focusing on specific metrification drivers on the three levels, this study elaborates how metrification emerges in a weak evaluation state (Gläser 2019; Whitley 2007). In addition, the empirical interrelatedness of all three levels provides links between the literature on metrification and quantification (e.g., Espeland and Sauder 2007; Heintz 2010, 2016) as well as on evaluation, valuation and valorization (e.g., Karpik 2010; Lamont 2012; Vatin 2013) and socio-calculative organizing (Vormbusch 2012; see also Gralka et al. 2019). Our study also contributes to the sociology of higher education and of sciences as it provides a complete picture of the publication behavior of different disciplines in Germany over the last 25 years. Using three surveys allows us to consider multiple types of publications. Databases such as Web of Science would not be appropriate as they do not cover humanities and social sciences publications, such as books, non-peer-reviewed articles and non-English journals, well (Ossenblok et al. 2012; Chi 2015). So our study can complete the picture especially with regard to humanities and social sciences (see Puuska 2014 for limitations of surveys).

We proceed as follows: In section 2, we describe the theoretical approach to auto-metrification and its varying forms at the systems, organizational and individual level. Each level corresponds to hypotheses regarding the change in publication behavior of academics. In section 3 , we describe the data and methods that we use to test the hypotheses. We use surveys conducted at three different points in time (1992, 2007 and 2018). In Germany, evaluations of academic work were introduced by federal government in the late 1990s. Accordingly, we assume that a change in publication patterns can be observed between the 1992 to the 2007 survey. Merit-based remuneration for professors became effective in 2005 . Accordingly, it is assumed that effects in terms of changes in publication outputs due to this reform are visible in the 2018 survey. The current dataset from 2018 also allows us to relate institutional evaluations to individual publication output. Section 4 presents the methods, section 5 the results and these are discussed in section 6. 


\section{Metrified Performance Recognition: The Auto-metrification of the German Academic Profession}

The auto-metrification of the German academic profession was first described by Schimank (2010, p. 239), although he did not label the process auto-metrification. Schimank (2010) elaborates how academics permit and accept that their achievement or performance is expressed by indicators that do not require interpretation by a competent member of the same academic discipline or field (see also Musselin 2013). For example, the Journal Impact Factor provides instant information for the "valuation" (Vatin 2013) of an article (Larivière and Sugimoto 2019). Accordingly, academics practicing auto-metrification do not have to wait (possibly) many years for peer evaluation as a mechanism of reputation gain, which is the substantial mechanism of "occupational control" (Freidson 2001). Even articles that are never cited $^{3}$ contribute to the reputation gain of an academic in accordance with the Journal Impact Factor: Due to academics' metrical salience Münch (2010, p. 343) refers to (peer-reviewed) articles in indexed, (highly) ranked journals as "status goods". The instant flagging of the success of status goods which are "structured, uncertain, and incommensurable" (Karpik 2010, p. 10), such as publications in high impact journals, makes publication-related metrics (indicators) an attractive coordination and evaluation or control mechanism for both academics and higher education and science governance. Indicators or metrics used for governance and control socially co-construct the reality of the "socio-calculative environment" (Vormbusch 2012 , p. 206) or, more precisely: the socio-calculative valuation, evaluation and valorization environment. According to Vormbusch (2012), indicators enable and create calculation practices: Calculation becomes social calculation by connecting the technical process of metrics' validation and social process of valorization, for example of a publication. Accordingly, the transformation of a social phenomenon into metrics precipitates a reflexive attribution of meaning. In the socio-calculative environment valuation is expressed by a certain metrical indicator (e.g., the number of citations and the Journal Impact Factor), which is evaluated according to the valuation regime ("assessment of value") and, therefore, valorized the indicator in the "production of value" or in the meaning of "to valorize, to give worth to" (Vatin 2013, p. 31, p 33). In other words: The reflexive social process of socio-calculative or economizing valuation is "based on evaluation and valorization", understanding also evaluation as an act of valorization (Vatin 2013, p. 32, p. 45).

\footnotetext{
${ }^{3}$ For example, a study by Qasim (2016, p. 1040) found that more than $50 \%$ of the papers about sustainability and well-being have not yet been cited; a study by Merigo et al. (2017, p. 529$)$ shows that $77 \%$ of the articles published in the International Journal of Intelligent Systems have only been cited once; both use the Web of Science database. In general, the average non-citation rate for social sciences articles is $22 \%$ (Nicolaisen and Frandsen 2019, p 1232).
} 
The socio-calculative valuation, evaluation and valorization environment of higher education and science governance enables the social construction of an "effectiveness frontier, i.e. an acceptable level of the desired outcomes" (De Witte and López-Torres 2017, p. 340). In addition, metrification allows for a quantitative differentiation of subjects, i.e., academics, and objects, i.e., HEls "by encompassing them under a shared cognitive system. At the same time, it also distinguishes objects [and subjects] by assigning to each one a precise amount of something that is measurably different from, or equal to, all others. Difference or similarity is expressed as magnitude, as an interval on a metric, a precise matter of more or less" (Espeland and Stevens 2008, p. 408). Metrics as a matter of more or less have to differentiate monetary and non-monetary (reputation-gain) recognition in the socio-calculative valuation, evaluation and valorization environment of higher education and science. Examples for monetary recognition are performance-based research funding (e.g., Whitley 2010; Woelert and McKenzie 2018) and professors receiving a certain percentage of their remuneration based on their performance in research, teaching, and knowledge and technology transfer (e.g., Klenke 2012; Leahey 2007). The best studied example of non-monetary recognition distribution is publications (e.g., Aagaard 2015; Braun 2012; Bornmann 2011; De Bellis 2009; Frey 2003; Gläser 2008; Gläser et al. 2002; Gläser and Laudel 2005; Hirschauer 2004, 2014; Laudel 2006, Laudel and Gläser 2014; van Leeuwen 2006; van Dalen and Henkens 2012; van Noorden 2010; Woelert 2015).

However, in the socio-calculative valuation, evaluation and valorization environment performance-based indicators for publications, third-party funding and other forms of performance communication can no longer be regarded separately but above all as a general state of mind in higher education and science governance. Therefore, metrified performance recognition (MPR) is selected as an umbrella term that summarizes monetary and nonmonetary forms of performance-based reward distribution and communication. The award of any kind of competitive funding or the publication of a manuscript in a peer-reviewed journal are considered to be recognition of an academic's (potential) merit or, in other words: reputation as a reward in terms of recognition for what an academic deserves (Honneth 2005; Mason 2003; Miller 1999). The desert principle is used to justify the general use of monetary and non-monetary rewards in MPR.

In Germany, the introduction and establishment of desert metrics as a means of and for governance (Desrosières 1998, 2000; Schmidt 2005) was a joint venture between the state and the academic profession. Scott (2005, p. 127) refers to this as the "continuum of professional-state relations", Stichweh (1994) as a traditional social partnership (Sozialpartnerschaft) and McClelland (1990) speaks of an "alliance" between the academic profession and the state (see also: Schimank 2005). Accordingly, the academic oligarchy in German higher education and science can strongly influence the creation and use of 
performance metrics for science administration and market-oriented decision-making (see also Espeland and Sauder 2007; Espeland and Stevens 2008). In the academic knowledge, beliefs and authority structures, the academic oligarchy refers to "the imperialistic thrust of modes of authority [...] in the way that personal and collegial forms, rooted in the disciplinary bottom of a system, work their way upward to have an important effect on enterprise and then finally system levels" (Clark 1983, p. 122). Professors govern through positions such as HEI leadership, academic senates, and also national academic entities, such as the German Rectors' Conference, the German Research Council and the German Research Foundation DFG (Brennan 2010; Pusser 2008). Accepting the hierarchical academic oligarchy structure, also less oligarchic professors are pushing MPR for publications, for example, the publication of manuscripts in Social Science Citation Index (SSCI) journals has become a formal requirement for the submission of a paper-based dissertation in several universities' $\mathrm{PhD}$ regulations (Schneijderberg 2018, p. 341ff.). Accordingly, MPR becomes part of the academic identity formation of future academics (e.g., Henkel 2005).

A salient example for the social partnership between the state and the academic oligarchy is the German Excellence Initiative (Exzellenzinitiative). The actors responsible for the content of the Excellence Initiative are the German Research Foundation DFG (Deutsche Forschungsgemeinschaft) and the German Science Council (Wissenschaftsrat). They also define indicators and other quality criteria used for the evaluation and selection of universities, research clusters and graduate schools in the initiative (DFG 2013; IECEEI 2016; Kehm 2006; Münch 2010). Another example for the social partnership between the state and the academic oligarchy is the introduction of MPR metrics with the so-called professorial W-remuneration scheme. According to the science historian Klenke (2012), the academic oligarchy in the form of the German Rectors' Conference supported the introduction of MPR (salary-relevant) metrics in exchange for more autonomy of HEls. Key events are the modification of the German higher education law in 1998 and the replacement of the so-called C-remuneration scheme for professors with the W-remuneration scheme in 2001 (Professorenbesoldungsreformgesetz; see also Waaijer 2015). ${ }^{4}$ The W-remuneration became effective in 2005. However, compared to US academics (Leahey 2007), the additional financial gain for German academics based on MPR achievements is small to moderate (Klenke 2012). Therefore, the normative power of metrics in "government at a distance" (Miller and Rose 1990, p. 9) is that the individual academic, academic department, HEI and academic community consent to (publication) indicators of MPR without necessarily receiving much monetary gain by doing so. The normative pressure of (publication) indicators in MPR trickles into self-

\footnotetext{
${ }^{4}$ In Germany, such a fundamental legal reform has to respect the academic freedom granted by the German constitution (Grundgesetz article 5(3)1), which offers relative protection to individual academics from interference by the state. However, the state is legally entitled to define governance principles within a specific purview (Bundesverfassungsgericht 2016).
} 
governance on the basis of "embodied practices" (Bourdieu 1995) or "bio-politics" (Foucault 2008,2010 ) implemented by academics who employ them for orientation in the field and/or auto-assurance, i.e., auto-evaluation within the academic community. The autopiloted metrical expression of value leads to a valuation of even unknown individuals, organizations and objects - valuation being the cumulative result of the sequential evaluation and valorization process (Mau 2018; Vatin 2013).

Based on the discussion above, the metrification (autopiloted) drivers can be roughly defined as trickle-up and trickle-down processes. The trickle-down process differentiates between (a) a political trickle-down process initiated by the use of indicators and other evaluation systems (Rijcke et al. 2016) and (b) the disciplinary trickle-down process initiated by comparison and adaptation of publication and citation behavior. The trickle-down processes into institutions and working practices of academics are accompanied by a trickle-up process initiated by individual behavior of academics. Accordingly, we study academics' publication behavior on three different levels: First, the most organized level of HEI MPR policy; second, the greater disciplinary academic community on the systems level; and, third, on the individual level the effects of academic rank and career stage. The goal is the study of the complex and intertwined metrification developments on the individual, organizational and discipline levels rather than the search for causal explanations (e.g., Gläser 2017; Osuna et al. 2011).

\subsection{Organizational Level of Auto-metrification}

The term auto-metrification highlights that it is not federal government but the academics themselves, more precisely the academic oligarchy, that are responsible for the introduction of MPR in general, and publication metrics in particular. By law, the individual states enable the use of MPR but do not define MPR measures, devolving this task to the academic senate and HEl leadership (e.g., Berlin 2011, § 8; Berlin 2018 [1996], § 3.3; Hesse 2009, § 36, § 37). Reforms in higher education have turned HEls into organizations with more autonomous leadership and managerial power (Krücken and Meier, 2006; Musselin, 2013). Within the legal framework set by the state, the HEI leadership, supported by boards and academic senates, exercises the relative autonomy of (not) setting MPR criteria in very different ways. Therefore, the auto-metrification of the academic profession via MPR ranges on a scale from nonexistent to highly explicit metrification (without clear intervals).

An example that tends toward the highly explicit end of the scale is the Technical University of Berlin (Table 1). According to the University's statute ${ }^{5}$ and guidelines, ${ }^{6}$ MPR can be granted

\footnotetext{
5

http://www.hochschulverband.de/fileadmin/redaktion/download/pdf/hsg/LBG/Berlin\%20TU\%20Satzung .pdf (last accessed 08 April 2020).

6

http://www.hochschulverband.de/fileadmin/redaktion/download/pdf/hsg/LBG/Berlin\%20TU\%20Richtlini en.pdf (last accessed 08 April 2020).
} 
for special achievements in research, teaching, teaching in continuing education courses or programs, doctoral education and training, and being an elected official, for example vicepresident or dean. The time period for calculating the performance credits is the last three years.

Table 1: "Performance credits" (Leistungspunkte) for scientific activities at the Technical University of Berlin (extract)

\begin{tabular}{ll}
\hline Indicator & Performance credits \\
\hline Book & 16 \\
Journal publication & 8 \\
Publication in edited volume & 2 \\
Electronic publication & 2 \\
Editing a book or journal & 4 \\
Third-party funding spent & $0.4 / 1,000$ Euro $^{a)}$ \\
Leibniz Award and ERC Advanced Grant & 300 \\
\hline
\end{tabular}

a) Up to the amount of 500,000 Euro. Hereafter the degression is: 0.3 performance credits for the next 500,000 Euro per 1,000 Euro, 0.2 performance credits per 1,000 Euro between one and two million Euro and 0.1 performance credits per 1,000 Euro for more than two million Euros.

Source: Gläser and Laudel (2019, p.193)

The performance credits system was established by the academic leadership and the academic senate of the TU Berlin, which also decided about the value of performance credits, i.e., the valorization expressed in performance credits is an expression of academic autometrification. In Table 1, the socio-calculative valuation, evaluation and valorization environment awards different numbers of credits for a book, a journal publication, the publication of an article in an edited volume and editing a book or journal. The number of credits for two journal publications are equal to the number for one book (which is also equal to spending 40,000 Euros of third-party funding).

The TU Berlin performance credits for journal publications do not differentiate whether the publication was peer-reviewed or published in an indexed journal. The latter is of great importance for some HEl departments. For example, the business and economics department of the University of Göttingen awards MPR according to the journal ranking of the Business and Management Association or the German Economics Association (for further details see annex 1). In general, the journals at the top of both associations' ranking lists are published in English. Accordingly, traditional publications in German language are classified as being of less metrical value and, in the case of publications in non-indexed journals, of no value. The examples provide a clear account for the valuation of publication outputs: Journal articles 
appear to be the most salient metrification indicator. The majority of indexed journals are English language journals, which can be captured by using the indicator non-German language publications. An additional salient feature of journal publications is peer review - knowing that the mode of peer review varies (e.g., single- and double-blind) (e.g., Bornmann 2011; Karpik 2011). Also the tendency toward shorter publication formats in humanities and social sciences is interpreted to be part of the metrification trend (e.g., Engels et al. 2012).

However, contrasting examples with regard to excluding publications from MPR can also be found: One HEl values only third-party funding as part of MPR. At another HEl one department acknowledges MPR achievements in the areas of successfully supervised PhDs and habilitations (10\%), third-party funding (40\%) and teaching (50\%), with teaching being subdivided into number of exams (25\%), bachelor and master theses supervised, and seminars for advanced students (10\%). The final example shows that the full extended metrification scale can also be applied to individual HEls. ${ }^{7}$ The presidency and academic senate of one HEl introduced MPR around the mid-2000s. The decision respects disciplinary differences concerning publication outputs and the amount of third-party funding. Therefore, it is left to the departments to set appropriate indicators, for example about the evaluation of books and journal publications. However, roughly one decade later it was decided that departments can choose whether or not to consider research and teaching in MPR. As a result, about $50 \%$ of the departments no longer apply research MPR and about $40 \%$ of the departments no longer apply teaching MPR.

The selected examples provide an idea of the diversity and idiosyncrasies of MPR application at the organizational level of HEls. Accordingly, we can classify HEls on the metrification scale from non-application to HEls making explicit and organized use of MPR. Theoretically, such socio-calculative valuation, evaluation and valorization practices govern and control academics, and interlock organizational and individual development (Vormbusch 2012). Therefore, in hypothesis $1(\mathrm{H} 1)$ we assume that more strongly an HEl applies MPR,
a) the higher the number of journal articles is
b) the higher the percentage of peer-reviewed articles is
c) the higher the percentage of co-authored articles is
d) the higher the percentage of non-German publications is, but
e) the lower the number of books is and
f) the lower the number of edited volumes is.

\footnotetext{
7 Unfortunately, the MPR criteria of most HEls are not publicly available. Therefore, we cannot provide references for some of our examples of academic auto-metrification. A selective list of $\mathrm{HEI}$ regulations about the W-remuneration is published by the German Association of University Professors and Lecturers (Deutscher Hochschulverband), see: https://www.hochschulverband.de/index.php?id=wbesoldung\#_(last accessed 08 April 2020).
} 


\subsection{System Level: Disciplinary Differences in Auto-metrification}

In the deduction of $\mathrm{H} 1$ it became clear that in certain HEls and departments MPR has clear disciplinary connotations, for example business and economics in Göttingen, and the focus on natural and technical sciences of the TU Berlin. The metrics-based competition in natural sciences is described by Heintz and Werron (2011) as the basis of the global success of the natural sciences' ideal, for example also in the social sciences disciplines of business and economics. The acceptance of journal publication metrics as the dominant reward principle has made the natural sciences the "model" (Cole 1983) for other disciplines. Adopting the natural sciences model and using the concomitant journal impact metrics in humanities, social and other sciences as indicators disregards the paradigm and non-paradigm differences between disciplines as constructed by Kuhn (1970). On metrification autopilot, academics in humanities, social and other sciences challenge disciplinary traditions of knowledge generation and distribution (Becher and Trowler 2001; Alexander von Humboldt-Stiftung 2008). For example, Dyachenko (2014) and Chi (2015) provide insights about the focus of humanities and social sciences research on more local problems, compared to the international problemsolving approach in natural sciences. For example, Flink and Simon (2014) stress the effects of peer pressure in academic communities toward more articles and more (peer-reviewed) publications, in addition to the politically initiated output orientation. De Rijcke et al. (2016, p. 163) emphasize that the policy change is only one "part in a broader development" in the adoption or striving for international ideals, which are formed by the natural sciences and pushed forward within a scientific community (see also: Osuna et al. 2011; Schimank 2010; Volkmann et al. 2014).

In general, the scientific community or communities are organized social "tribes" with their cognitive "territory" (Becher and Trowler 2001). Similar to universities as organizations, also such a social tribe can be theorized as an (international) organizing entity, which strives for (more) coherence of individual and organizational development in the socio-calculative valuation, evaluation and valorization environment (Vormbusch 2012). MPR is reported by several studies to be effective also in humanities and social sciences communities (e.g., Haddow and Hammarfelt 2019; Larivière and Sugimoto 2019). Accordingly, the interdependence of calculation practices and social valuation, evaluation and valorization practices can be theorized as a general organizing phenomenon of academic communities. "Indicators as judgment devices" (Hammarfelt and Rushforth 2017) seem to be applied for governance and control both by the disciplinary academic oligarchy (trickle-down) and newer researchers (trickle-up). Independent of disciplinary differences in knowledge generation and communication, the trickle-down and trickle-up pressures are causing a change in publication patterns among humanities and social sciences scholars: Altogether the share of publications by humanities and social sciences scholars from non-English speaking countries has 
increased in general and in peer-reviewed journal publications in particular (e.g., Hammarfelt and de Rijcke 2015; Kulczycki et al. 2018). In addition, co-authorship has increased in publications by humanities and social sciences scholars (Henriksen 2016; Ossenblok et al. 2014). In social sciences, the number of monographs published per author has decreased over time (e.g., Engels et al. 2012). The metrification pressures do not imply that publication patterns have changed completely. For example, Puuska (2014) shows that in humanities books remain important, but observes a shift from monographs to edited volumes.

Referring to the observed shifts in publication output based on socio-calculative valuation, evaluation and valorization practices, hypothesis $2(\mathrm{H} 2)$ assumes that the publication outputs in other disciplines are converging with publication outputs in natural sciences resulting in

a) an increase in the number of journal publications,

b) an increase in the percentage of peer-reviewed publications,

c) an increase in the percentage of non-German language publications,

d) an increase in the percentage of co-authored publications,

e) a decrease in the number of book publications, and

f) a decrease in the number of edited books.

\subsection{Individual Level Auto-metrification}

In a socio-calculative valuation, evaluation and valorization environment metrical indicators appear to be rational and objective, which is esteemed by academics (Mau 2018, p. 128). And metrics, such as the $\mathrm{H}$ - and Ha-index (Leydesdorff et al. 2019), are easy and efficient status markers that make research success visible (Mau 2018, p. 127). The acceptance of metrics and the auto-metrification of the academic profession seem to make the implicit explicit as academics have always strived for reputation (and money) in the highly stratified competitive arena of the sciences (Bol et al. 2018; Bourdieu 1975; Cole and Cole 1973; Huber 1998; Larivière and Gingras 2010; Latour and Woolgar 1979; Merton 1968; Petersen et al. 2011; Stephan and Levin 1992). Therefore, we assume that the socio-calculative valuation, evaluation and valorization driving forces of auto-metrification and its effects can be observed by looking separately at publication outputs of full professors (status categories $\mathrm{C} 4, \mathrm{C} 3, \mathrm{C}$, W2 and W3 positions) and non-full professors (PhD candidates, post-docs and junior or assistant professors with W1 positions).

In addition to general expectations of scientific quality and academic productivity (Lynn et al. 2009), we would expect that non-full professors aspiring to become full professors and newer full professors are most susceptible to the metrification paradigm. First, newer full professors are subject to the MPR-based W-remuneration scheme and not the pre-2005 C-remuneration without MPR. Second, newer full professors have to metrically prove their worth in the professorial community and to metrically distance themselves from academics in lower status 
groups. Therefore, we assume in hypothesis $3(\mathrm{H} 3)$ that, in comparison to older full professors, newer full professors have a

a) higher number of journal publications,

b) higher percentage of peer-reviewed publications,

c) higher percentage of non-German language publications,

d) higher percentage of co-authored publications,

e) lower number of book publications, and

f) lower number of edited books.

The group of non-full professors has to be differentiated according to early career academics doing their $\mathrm{PhD},{ }^{8}$ post-docs working on their Habilitation, researcher and junior professor positions and, generally, permanent, non-qualification positions (Wissenschaftszeitvertragsgesetz 2016). Qualification publications, i.e., a Habilitation or PhD thesis can be either a book or a collection of published papers. Unlike for the Habilitation, information about the form of $\mathrm{PhD}$ publications is publicly available: In the winter semester 2014/15, on average $23 \%$ of PhDs were collections of papers (GFSO 2016a, p. 32; see also Schneijderberg 2018), and, therefore, the book is the norm, even in natural sciences (72\%; social sciences (incl. law, business and economics) $76 \%$; engineering $86 \%$; humanities $87 \%)$. Accordingly, PhD candidates only partly become acquainted with the "publish or perish" (Backes-Gellner and Schlinghoff 2010) culture. The metrified publish or perish culture affects non-full professors who know that each SSCl-indexed and refereed journal article and each monograph increases their chances for tenure (Jungbauer-Gans and Gross 2013), for example for sociologists by 10 to $15 \%$ (Lutter and Schröder 2016). Accordingly, hypothesis 4 (H4) assumes that, in comparison to other non-full professors, post-docs doing a Habilitation, researcher and junior professor positions have a

a) higher number of journal publications,

b) higher percentage of peer-reviewed publications,

c) higher percentage of non-German language publications,

d) higher percentage of co-authored publications,

e) lower number of book publications, and

f) lower number of edited books.

\footnotetext{
8 In Germany, the PhD is considered the first phase of practice-based training. The vast majority of $\mathrm{PhD}$ candidates is employed at an $\mathrm{HEl}$, i.e., $\mathrm{PhD}$ candidates are not students (in Germany, only about $23 \%$ of PhDs have (additional) student status; BuWiN, 2017, p. 154).
} 


\section{Data}

To answer our research questions and the related four hypotheses (Table 2) we use the German data from three international follow-up surveys, which allows us to compare the three surveys and observe trends in the academic profession over time: The Carnegie Foundation study from 1992 (from now on "Carnegie 1992"), the CAP study (Changing Academic Profession, "CAP 2007") from 2007 and the APIKS ${ }^{9}$ study (Academic Profession in Knowledge Societies, “APIKS 2018”) from 2018. The international study Carnegie 1992 was conducted on initiative of the Carnegie Foundation, which regularly conducts surveys on the academic profession in the USA, now with the goal to broaden the scope to an international perspective (Boyer et al. 1994; Enders and Teichler 1995a). CAP 2007 was initiated by an international researcher group with the goal to observe changing conditions in the academic profession in comparison to Carnegie 1992. Subsequently, the questionnaire has been expanded with current topics (Jacob and Teichler 2011, p.13). Similarly, APIKS 2018 was conducted as an international survey with the possibility of observing changes (compared to Carnegie 1992, and CAP 2007) and an extra focus on the topic of the knowledge society (therefore: Academic Profession in Knowledge Society). All three German parts of these international surveys were conducted by The International Centre for Higher Education Research-Kassel (INCHER) (at time of Carnegie 1992 INCHER was called Centre for Research on Higher Education and Work). The German part of the Carnegie 1992 survey only questioned academics in West Germany; higher education institutions in East Germany were undergoing a period of change due to the reunification of Germany (Jacob and Teichler 2011, p.12).

The target population is academics with full-time employment or at least half-time employment at universities and Universities of Applied Sciences in Germany. In Carnegie 1992 the sampling was based on two-stage sampling: In the first stage, $18 \mathrm{HEls}$ were sampled randomly. From these HEls, a full sample (cluster) of the academic profession was taken (Enders and Teichler 1995b). In CAP 2007 sampling was different for full professors and nonfull professors. Full professors were sampled via stratified random sampling (strata: gender, disciplines) using Kürschner Deutscher Gelehrten Kalender 2007 (an encyclopedia that contains a biographical list of all professors in Germany). Non-full professors in CAP 2007 were sampled via two-stage stratified random sampling. In a first stage 101 out of $339 \mathrm{HEls}$ were sampled and then in these HEls the non-full professors were sampled (strata on HEI level: type, region, third-party funding of university, type of staff; strata on the individual level: gender and discipline) (Jacob and Teichler 2011). Full professors were over-sampled in CAP as they are the specific target group. However, this should not affect our analyses as we analyze only full professors in hypotheses 1,2 and 3 and distinguish between full and non-full

\footnotetext{
${ }^{9}$ The APIKS data will be available for other scientists in 2021 hosted by GESIS - Leibnitz Institut für Sozialwissenschaften.
} 
professors in hypothesis 4. In APIKS 2018, two-stage sampling was used. In a first stage, HEls were sampled: A random sample of $24 \mathrm{HEls}$ stratified by type, region and size. From these HEls a full cluster of academics was targeted.

Table 2: Representativeness of Carnegie 1992, CAP 2007 and APIKS 2018 Samples

\begin{tabular}{|c|c|c|c|c|c|c|}
\hline & \multicolumn{2}{|c|}{ Carnegie } & \multicolumn{2}{|c|}{ CAP } & \multicolumn{2}{|c|}{ APIKS } \\
\hline & $\begin{array}{c}1992 \\
\text { (Population)* }\end{array}$ & $\begin{array}{c}1992 \\
(\text { Sample)* }\end{array}$ & $\begin{array}{c}2007 \\
\text { (Prof. } \\
\text { population) }\end{array}$ & $\begin{array}{c}2007 \\
\text { Prof. } \\
\text { (sample) }\end{array}$ & $\begin{array}{c}2018 \\
\text { (Prof. } \\
\text { population) }\end{array}$ & $\begin{array}{c}2018 \\
\text { (Prof. } \\
\text { sample) }\end{array}$ \\
\hline Gender $^{\star \star *}$ & & & & & & \\
\hline male & $84 \%(86,213)$ & $83.3 \%$ & $\begin{array}{l}84 \% \\
(31,883)\end{array}$ & $83.3 \%$ & $\begin{array}{l}76.2 \% \\
(28,848)\end{array}$ & $75.8 \%$ \\
\hline female & $16 \%(16,421)$ & $16.7 \%$ & $\begin{array}{l}16.2 \% \\
(6,173) \\
\end{array}$ & $16.7 \%$ & $\begin{array}{l}23.8 \% \\
(11,904)\end{array}$ & $24.2 \%$ \\
\hline Org. Type: & & & & & & \\
\hline Universities & $90 \%(92,371)$ & $91.3 \%$ & $\begin{array}{l}60 \% \\
(20,959)\end{array}$ & $67.2 \%$ & $\begin{array}{l}58 \% \\
(22,712)\end{array}$ & $58.3 \%$ \\
\hline UAS & $10 \%(10,263)$ & $8.7 \%$ & $\begin{array}{l}40 \% \\
(14,424)\end{array}$ & $32.8 \%$ & $\begin{array}{l}42 \% \\
(16,311)\end{array}$ & $41.7 \%$ \\
\hline $\begin{array}{r}\text { Others }{ }^{* *} \\
\text { (not included) }\end{array}$ & ** & ** & ${ }^{* *}(2,637)$ & ** & ** $(2,912)$ & ** \\
\hline Subject area & & & & & & \\
\hline $\begin{array}{r}\text { Natural } \\
\text { Sciences }\end{array}$ & $37 \%(26,685)$ & $39.2 \%$ & $\begin{array}{l}26.4 \% \\
(7,849)\end{array}$ & $25.2 \%$ & $17 \%(6,418)$ & $23 \%$ \\
\hline Engineering & $24 \%(17,448)$ & $18.1 \%$ & $\begin{array}{l}27 \% \\
(8,000) \\
\end{array}$ & $25.6 \%$ & $\begin{array}{l}32.9 \% \\
(12,453)\end{array}$ & $33.9 \%$ \\
\hline $\begin{array}{r}\text { Social } \\
\text { Sciences (incl. } \\
\text { Law and } \\
\text { Economics) }\end{array}$ & $\begin{array}{l}17.4 \% \\
(12,316)\end{array}$ & $26.3 \%$ & $\begin{array}{l}27.4 \% \\
(8,128)\end{array}$ & $30.8 \%$ & $\begin{array}{l}37.8 \% \\
(14298)\end{array}$ & $25.6 \%$ \\
\hline Humanities & $\begin{array}{l}20.3 \% \\
(14,369)\end{array}$ & $16.4 \%$ & $\begin{array}{l}19.2 \% \\
(5,710) \\
\end{array}$ & $18.3 \%$ & $12 \%(4,689)$ & $17.5 \%$ \\
\hline Others & ${ }^{* * *}(31,816)$ & *** & *** $(8,333)$ & $* * *$ & ${ }^{* * *}(10,270)$ & *** \\
\hline Total & 102,634 & 2,277 & 38,020 & 305 & 35,675 & 990 \\
\hline
\end{tabular}

\footnotetext{
* We use the total number of academic staff (including all scientific positions employed at more than $50 \%$ of fulltime (hauptberufliches wissenschaftliches Personal), no official statistics for professors are available for 1992. ** Other organizational types were excluded from the analysis (music and art colleges, Gesamthochschule).

${ }^{* * *}$ Medicine, agriculture and forestry, sports, arts, and central facilities (not included in analysis). Accordingly, they are not integrated in the percent counts.

Sources: German Federal Statistical Office (2018): Personal an Hochschulen 2018. Fachserie 11 Reihe 4.4, own calculations; German Federal Statistical Office (2007): Personal an Hochschulen 2017. Fachserie 11 Reihe 4.4, own calculations; Enders, J. \& Teichler, U. (1995b). Berufsbild der Lehrenden und Forschenden an Hochschulen. Ergebnisse einer Befragung des wissenschaftlichen Personals an westdeutschen Hochschulen. Bonn:

Bundesministerium für Bildung, Wissenschaft, Forschung und Technologie.
}

The distributions of gender, the organizational types included (University and University of Applied Sciences) and the disciplines analyzed were nearly representative in all three surveys (Table 2). ${ }^{10}$ Response rates were similar in each study, Carnegie 1992: 28 \%, CAP 2007: $32 \%$, APIKS: 28 \% (Enders and Teichler 2007, Teichler et al. 2013).

10 In Carnegie 1992 the disciplines in the final sample are not completely distributed in the same way as in the population, especially medicine is too low (Enders and Teichler 1995b). However, medicine is not used for our analysis and for other disciplines we either run separate analyses or use discipline as 
The three studies are thus not constructed as a panel. Each of the three studies draws a new cross-sectional sample of academics (full professors and non-full professors) working at a university or a University of Applied Sciences in Germany. For our analysis we can include the following samples: Full professors: Carnegie $1992 \mathrm{n}=661$; CAP $2007 \mathrm{n}=305$; APIKS $2018 \mathrm{n}$ = 990; non-full professors: Carnegie 1992 not included; CAP 2007 n = 249; APIKS 2018 n = 3,008. ${ }^{11}$

The studies focus on everyday working activities and attitudes of academic professionals toward their jobs in higher education: research, teaching and learning, governance, transfer activities, as well as career paths (Enders and Teichler 1995a, 1995b; Altbach 1996; Jacob and Teichler 2011; Teichler et al. 2013). A major advantage of these surveys for our purpose is a differentiated question about all kinds of publication types. In contrast, bibliometric databases are not well suited for analyzing publications in the humanities and social sciences (Chi 2015). In these academic fields the publication patterns are more diverse and do not only comprise English language and international publications as focused on by the Web of Science (Kyvik 2003; Hicks and Wang 2011).

For our research purpose, the total sample analyzed differs for each hypothesis because the target group and the available variables in the datasets differ with respect to each research question (Table 3). For $\mathrm{H} 1, \mathrm{H} 2$ and $\mathrm{H} 3$ we focus on full professors because lower rank academics are not considered the typical academics in cross-country comparative surveys (Kyvik and Olsen 2008; Kyvik and Aksnes 2015). H1 focuses on actual organizational policy. Therefore, we use only APIKS 2018 data because organizational level data is not available in Carnegie 1992 and CAP 2007. In H2, we assume that the other disciplines change their publication patterns over time toward a more metrified pattern, which is common in the natural sciences. We are interested in a change of publication patterns in other disciplines. Therefore, we run separate analyses for each discipline so that we can observe changes over time in each discipline. An addition, the overall analysis shows whether the publication patterns are now more similar between natural sciences and other disciplines or not. $\mathrm{H} 3$ and $\mathrm{H} 4$ use CAP 2007 and APIKS 2018 because the variable 'time in this status position' is not included in Carnegie 1992. We further include non-full professors (junior professors, non- professorial academic staff) to analyze developments, commonalities and differences between established and newer academics (Teichler et al. 2013, p. 149; Kyvik and Aksnes 2015).

Our output variables measure the quantity of different publication types per author. The three surveys use two different measures for the quantity of publications. First, journal articles and

a control. In CAP 2007, there is a nearly representative distribution of organizational types (university and Universities of Applied Sciences), disciplines, and gender (Bracht 2008). In APIKS 2018, the discipline of the residual category "other" (such as sports) is slightly underrepresented.

11 Each study aimed for a different sample size. For example, the CAP 2007 study aimed for 800 respondents. The APIKS 2018 study aimed for a full sample of the $24 \mathrm{HEIs.}$ 
books (one item for books as author, one item for books as editor) are measured as numbers or so called count variables ("how many of the following scholarly contributions have you completed in the past three years?"). Second, peer-reviewed contributions, non-German language publications ("published in a foreign country") and co-authored publications (one item for national and one item for international collaboration) are measured as a percentage ("What percentage of your publications in the last three years were..."). The publication output always relates to the last three years. This is an appropriate measure (Abramo et al. 2012). Shorter periods of measurement are not robust against random components and longer periods are not able to detect important variations during a period (Abramo et al. 2012). In line with our argumentation, journal articles, peer-reviewed contributions, non-German language publications and co-authored publications are considered as metrified output, whereas books and edited books are considered as non-metrified output.

The three surveys (Carnegie 1992, CAP 2007 and APIKS 2018) provide an opportunity to observe changes in publication behavior in the academic profession over time. Table 3 shows the survey data used for each hypothesis. As not all of the three surveys contain all variables, not all analyses contain data from all three studies. The variables measured as a percentage (peer-reviewed contributions, non-German language publications and co-authored publications) are only collected in CAP 2007 and APIKS 2018. Further, the variable measuring journal articles changes slightly over time: The item regarding the number of "chapters in edited books/journal articles" is measured as one composite item in the questionnaires for Carnegie 1992 and CAP 2007. However, APIKS 2018 uses two specific items that respondents can choose between number of "journal articles" and number of "book chapters". Therefore, H1 relies only on APIKS 2018 data, which can identify journal articles. 
Table 3: Hypotheses, Methods, and Data

Hypothesis HEls with a stronger research performance orientation are related to a higher (+) / lower (-) individual research output of the following publications

\begin{tabular}{|c|c|c|c|c|c|c|}
\hline 1a & + & Journal articles (journal articles) & Multilevel negative binomial regression & \multirow{5}{*}{\multicolumn{2}{|c|}{$\begin{array}{l}\text { no (hypothesis aims for relationship between } \\
\text { organization and individual publications in 2018) }\end{array}$}} & yes \\
\hline $1 b$ & + & Peer reviewed contributions & Multilevel generalized linear model & & & yes \\
\hline & + & non-German language publications & Multilevel generalized linear model & & & yes \\
\hline & + & co-authored publications (national and international) & Multilevel generalized linear model & & & yes \\
\hline \multirow[t]{2}{*}{ e } & - & book publications (author and editor) & Multilevel negative binomial regression & & & yes \\
\hline & \multicolumn{6}{|c|}{ Over time (1992, 2007 to 2018) there is a growing (+)/ decreasing (-) number of the following publications per academic researcher } \\
\hline & + & Journal articles (journal articles + edited book chapters) & Negative binomial regression & yes & yes & yes \\
\hline & + & Peer reviewed contributions & Fractional logit regression & no (items not in questionnaire) & yes & yes \\
\hline & + & non-German language publications & Fractional logit regression & no (items not in questionnaire) & yes & yes \\
\hline & + & co-authored publications (national and international) & Fractional logit regression & no (items not in questionnaire) & yes & yes \\
\hline \multirow[t]{2}{*}{$2 e$} & - & book publications (author and editor) & Negative binomial regression & yes & yes & yes \\
\hline & \multicolumn{6}{|c|}{ Professors who are newer in this position have a higher (+)/lower (-) publication output compared to longer established professors. } \\
\hline & + & Journal articles (journal articles + edited book chapters) & Negative binomial regression & no (items not in questionnaire) & yes & yes \\
\hline & + & Peer reviewed contributions & Fractional logit regression & no (items not in questionnaire) & yes & yes \\
\hline 3 & + & non-German language publications & Fractional logit regression & no (items not in questionnaire) & yes & yes \\
\hline & + & co-authored publications (national and international) & Fractional logit regression & no (items not in questionnaire) & yes & yes \\
\hline & - & book publications (author and editor) & Negative binomial regression & no (items not in questionnaire) & yes & yes \\
\hline
\end{tabular}

Beginning with the Post-Doc phase, non-full professors who are newer in this position have a higher (+)/lower (-) publication output compared to longer established non-full professors. Very new non-full professors in their PhD phase are assumed to have an overall lower output.

4a + Journal articles (journal articles + edited book chapters)

4b + Peer reviewed contributions
Negative binomial regression

Fractional logit regression

Fractional logit regression

Fractional logit regression

Negative binomial regression

$\mid \begin{array}{lll}\text { no (items not in questionnaire) } & \text { yes } & \text { yes } \\ \text { no (items not in questionnaire) } & \text { yes } & \text { yes } \\ \text { no (items not in questionnaire) } & \text { yes } & \text { yes } \\ \text { no (items not in questionnaire) } & \text { yes } & \text { yes } \\ \text { no (items not in questionnaire) } & \text { yes } & \text { yes }\end{array}$


We use organizational performance orientation as a proxy indicator for publication MPR of an $\mathrm{HEI}$ in $\mathrm{H} 1$. For this purpose, we calculated the aggregated mean variable per HEI of the individual level item: "At your institution, there is a very strong research performance orientation" (from 1 strongly disagree to 5 strongly agree). The item focuses on the "strong research performance orientation", which we consider the basis of any kind of output or outcome valuation, evaluation and valorization, and, therefore, suitable as a MPR proxy. In addition, several studies (e.g., Hammarfelt and de Rijcke 2015; Laudel and Gläser 2006) suggest that performance measurement keywords, such as indicator, metric, etc., provoke defensive attitudes, for example among professors in humanities and social sciences. The aggregated mean of this variable serves as an organizational variable. Thus in the analysis of $\mathrm{H} 1$, the organizational performance indicator is the aggregated mean of the individual indicator per HEl. This means that every individual academic at one $\mathrm{HEl}$ has the same value for organizational performance orientation. Accordingly, an HEI with an MPR system has a higher mean value for the item "strong research performance orientation". ${ }^{12}$

Our main explanatory variable in $\mathrm{H} 2$ is the year, corresponding to the surveys: 1992, 2007 and 2018. These three points in time fit to the developments in the German higher education system (see section 2). We analyze the following academic fields: natural sciences, engineering, humanities, social sciences, and economics. As $\mathrm{H} 2$ assumes an adaptation toward the natural sciences, we run these analyses separately for each academic field. When analyzing the other questions, we use academic field as a control variable. To investigate $\mathrm{H} 3$ and $\mathrm{H} 4$ we categorize the two status groups (full professors vs. non-full professors) according to years of belonging to the respective status group. We analyze both hypotheses for the year 2007 (CAP) and the year 2018 (APIKS) separately.

In general, a new academic has six years to finish her/his $\mathrm{PhD}$ thesis and another six years for the Habilitation (Wissenschaftszeitvertragsgesetz 2016). Furthermore, the average duration of a professorship is 24 years (average age of becoming full professor in Germany is about 41 years; retirement age 67). Accordingly, full professors are categorized as follows: being in this status position for up to 6 years, from 7 to 12 years, from 13 to 18 years, and 19 years and more; and non-full professors are categorized as being in this status for up to 6 years, from 7 to 12 years, and 13 years and more. Categorizations follow six-year steps because these periods are crucial landmarks in the German academic system.

\footnotetext{
12 Although it has already been used in other studies (e.g., Poland, see Kwiek 2018 and for South Korea see Shin and Cummings 2010), we further investigated the variable's usefulness. We relate the HEls that are known to have an MPR or are part of the Excellence Initiative (IECEEI 2016; Kehm 2006) to the research performance orientation of $\mathrm{HEI}$, which was individually assessed by the survey respondents. As table A1 (see annex 2) shows, there is a relationship between HEls with an MPR and research performance orientation item in the survey. Thus, it is reliable to use this measure as a proxy for HEls with MPR. The variable on the individual level is aggregated so it can be used on the institutional level (Shin and Cummings 2010).
} 
In $\mathrm{H} 3$ we expect that newer professors (0-6 years in the position) have more metrified publications than the more established professors because the latter became professors when the metrification norms were less strong. Therefore, the category 0-6 years in the position of a professor is the reference category. In $\mathrm{H} 4$, we expect that non-full professors have most metrified publications when they have been in their position for 7-12 years. In the first 6 years, when they are in the $\mathrm{PhD}$ phase, they become socialized into academia and only gradually start publishing (in general, not only with regard to metrified publications). In years 7-12 nonfull professors are in their post-doc and Habilitation phase and metrified publications are crucial for getting a full professorship (Jungbauer-Gans and Gross 2013; Önder and Schweitzer 2017). Non-full professors who have been in the system for 13 and more years are expected to publish less than the non-full professors in the years 7-12. In APIKS 2018 respondents who have been in their status positions for " 13 years and more" started their academic careers in an earlier cohort when the metrification norms were less strong. In addition, a fair number of non-full professorial academics surviving 13 years and more in HEls have permanent contracts (e.g., lecturers) (GFSO 2018a). Therefore, the reference category is "7-12 years" as these academics are expected to produce the most metrified publications.

We further control for personal and organizational characteristics related to publication output (Bentley 2012; Hopkins et al. 2013; Jacobs and Ingwersen 2000): gender, type of HEl (university vs. University of Applied Sciences), years of employment in HEls, and specifically for full professors: type of qualification (habilitation vs. $\mathrm{PhD}$ and below), and non-full professors (type of contract: permanently employed or fixed term). Descriptive statistics of the employment data, divided by study (Carnegie 1992, CAP 2007, and APIKS 2018) and by status (full professor vs. non-full professor) are presented in Table 4. 
Table 4: Descriptive statistics

\begin{tabular}{|c|c|c|c|c|c|c|c|}
\hline & & $\begin{array}{l}\text { Full Professors } \\
\text { Carnegie } 1992 \\
\end{array}$ & CAP 2007 & APIKS 2018 & $\begin{array}{l}\text { Non-Full Professc } \\
\text { CAP } 2007\end{array}$ & & APIKS 2018 \\
\hline & \multicolumn{4}{|c|}{ Mean(Std. Dev, Min-Max) } & & & \\
\hline \multirow[t]{8}{*}{ Publication type } & Journal articles & $7.62(9.00,0-85)$ & $11.31(12.98,0-120)$ & $10.15(11.26,0-100)$ & $5.14(6.29,0-45)$ & & $4.36(7.00,0-200)$ \\
\hline & Books & $0.72(1.31,0-20)$ & $0.59(1.03,0-10)$ & $0.52(1.16,0-20)$ & $0.28(0.54,0-2)$ & & $0.18(0.47,0-5)$ \\
\hline & Edited books & $0.81(1.52,0-15)$ & $1.05(2.01,0-22)$ & $0.79(1.60,0-20)$ & $0.15(0.59,0-6)$ & & $0.18(0.74,0-25)$ \\
\hline & Peer reviewed contributions (fraction) & $-*$ & $0.40(0.40,0-1)$ & $0.51(0.39,0-1)$ & $0.47(0.40,0-1)$ & & $0.53(0.41,0-1)$ \\
\hline & Non-German language (fraction) & $-*$ & $0.34(0.37,0-1)$ & $0.40(0.39,0-1)$ & $0.40(0.40,0-1)$ & & $0.40(0.41,0-1)$ \\
\hline & Co-author Germany (fraction) & $-{ }^{*}$ & $0.44(0.36,0-1)$ & $0.45(0.36,0-1)$ & $0.55(0.40,0-1)$ & & $0.56(0.40,0-1)$ \\
\hline & Co-author Foreign (fraction) & - * & $0.16(0.24,0-1)$ & $0.20(0.28,0-1)$ & $0.18(0.30,0-1)$ & & $0.18(0.30,0-1)$ \\
\hline & \multicolumn{4}{|c|}{ Percentage } & & & \\
\hline \multirow[t]{2}{*}{ Gender } & Male & 94.70 & 83.28 & 75.76 & 74.70 & & 60.47 \\
\hline & Female & 5.30 & 16.72 & 24.24 & 25.30 & & 39.53 \\
\hline \multirow[t]{2}{*}{ Type } & University & 77.16 & 67.21 & 58.28 & 96.79 & & 94.18 \\
\hline & University of Applied Sciences & 22.84 & 32.79 & 41.72 & 3.21 & & 5.82 \\
\hline \multirow[t]{5}{*}{ Subject area } & Natural Sciences & 31.62 & 25.25 & 23.03 & 40.16 & & 39.89 \\
\hline & Engineering & 18.61 & 25.57 & 33.94 & 28.51 & & 21.04 \\
\hline & Social Sciences & 18.91 & 18.36 & 15.56 & 13.65 & & 18.55 \\
\hline & Humanities & 23.75 & 18.36 & 17.47 & 10.44 & & 15.43 \\
\hline & Economics/Business & 7.11 & 12.46 & 10.00 & 7.23 & & 5.08 \\
\hline \multirow[t]{2}{*}{ Contract } & Tenured/Permanently employed & 98.32 & 94.41 & 96.35 & 29.72 & & 12.97 \\
\hline & Fixed-term & 1.68 & 5.59 & 3.65 & 70.28 & & 87.03 \\
\hline \multirow[t]{2}{*}{ Highest Degree } & Highest Degree Habil & 56.43 & 56.39 & 40.20 & $-*$ & & $-*$ \\
\hline & $\mathrm{PhD}$ or below & 43.57 & 43.61 & 59.80 & $-*$ & & $-*$ \\
\hline \multirow[t]{5}{*}{ Years in position in $\mathrm{HE}$} & (0 - 6 years $)$ & $-{ }^{*}$ & 40.34 & 31.31 & 53.82 & & 56.42 \\
\hline & (7 - 12 years) & $-*$ & 27.46 & 27.66 & 24.10 & & 26.36 \\
\hline & (13 - 18 years) & $-*$ & 20.00 & 24.69 & 22.09 & & 17.22 \\
\hline & (19 or more years) (only prof) & - * & 12.20 & 16.34 & - & & - \\
\hline & \multicolumn{4}{|c|}{ Mean(Std. Dev, Min-Max) } & & & \\
\hline \multirow[t]{4}{*}{ Organizational MPR } & Institutional level (Hypothesis 1) & $-{ }^{*}$ & $-{ }^{*}$ & $3.36(0.53,2.14-4.13)$ & $-*$ & & $-*$ \\
\hline & Individual level (Hypothesis 1) & $-{ }^{*}$ & $-*$ & $3.34(1.16,1-5)$ & $-*$ & & $-*$ \\
\hline & $\mathrm{N}$ & 661 & 305 & 990 & & 249 & 3008 \\
\hline & \multicolumn{7}{|c|}{ For some hypotheses the case numbers (or N) are slightly lower than displayed here. } \\
\hline
\end{tabular}




\section{Methods}

We use several publication types as outcome variables. All hypotheses, methods and data are displayed in Table 3. We use regression models to predict our outcomes. We assume that metrification autopilot is related to organizational performance orientation (MPR) (H1), the passage of time $(\mathrm{H} 2)$, or to rank and number of years in the current status position $(\mathrm{H} 3$ and $\mathrm{H} 4)$. In addition to the assumed relationships in our hypotheses, publication patterns are also assumed to be affected by other organizational and individual characteristics (e.g., Puuska 2010). These need to be controlled if the metrification autopilot is to be identified as a general trend and not related to, for example, the different distribution of gender in academia over time. The type and distribution of the outcome variables indicate a specific regression model. Journal articles and (edited) books are measured as numbers. This so-called count data indicates how many times an event occurs in a given interval (Long and Freese 2014, Sec. 9; examples: Henriksen 2018; Bornmann and Daniel 2016), for example, how many articles an academic published in the last three years. For count data, we apply negative binomial regressions. These models are preferred over Poisson regressions as publication/citation data is typically overdispersed: Overdispersion means that the variance is higher than the mean. Publication data is typically skewed (see also Bornmann et al. 2010, p. 109) as a few academics have many publications whereas the majority of academics have few publications (Lotka 1926; de Solla Price 1963; Saam and Reiter 1999). Overdispersion in our data has also been tested using a likelihood-ratio test (Long and Freese 2014, p.511).

Peer-reviewed contributions, non-German language publications and co-authored publications are measured in percentage. We divide them by 100 and use them as fractions (values between 0 and 1 instead of $0 \%$ and $100 \%$ ). For the outcomes measured in fractions we use fractional response models (Papke and Wooldridge 1996). These models are used to analyze a fraction of a total, e.g., the fraction of peer-reviewed publications of all publications. These models also manage fractional outcomes that are bounded between 0 and 1 when the outcome is equal to the extreme values of 0 or 1 .

$\mathrm{H} 1$ assumes an association between the organizational performance orientation of the HEI and the publication output of the individual academic. These characteristics indicate the appropriateness of a multilevel model (Rabe-Hesketh and Skrondal 2012). This model takes into account that processes operate "at different levels, for instance, people's characteristics interact with institutional characteristics" (Rabe-Hesketh and Skrondal 2012, p. xxv). In our cases, these are professors in HEls who are assumed to be affected by the HEl's organizational performance orientation, which is expected to result in a higher metrified output. Thus, here the dependency of individuals' output (publications) on a higher unit (HEI) is the core of H1 (Snijders and Bosker 2012). Multilevel models can model the variance of a first level 
(individual) and of a second level (HEI) variance component (Rabe-Hesketh and Skrondal 2012). In our final analysis sample for $\mathrm{H} 1$ we have $23 \mathrm{HEls}^{13}$ (second level) with between 12 and 91 full professors. Accordingly, our output variables are count data (journal articles and (edited) books), which is analyzed using multilevel negative binomial regression. Fractional data (peer-reviewed, non-German language and co-authored publications) is modeled as a multilevel generalized linear model with a binomial distribution and a logit link. With this specification we can adapt the fractional model for multilevel use. A generalized linear model is appropriate as it can relax the assumptions of an ordinary linear regression (Hardin and Hilbe 2013). For fractional data the distribution is binomial and the relation between the linear predictor and the expected value is modeled as a logit link (Hardin and Hilbe 2012, p. 167; Stata command xtgee). For robustness checks of $\mathrm{H} 1$, we use ordinary models (i.e., single level instead of multilevel) with cluster robust standard errors (individuals clustered in HEls). All other hypotheses $(\mathrm{H} 2, \mathrm{H} 3$, and $\mathrm{H} 4)$ are analyzed as single level models (individual level). All analyses were conducted using Stata 14 (StataCorp 2015).

\section{Results}

In the following, we present the results for our hypotheses. $\mathrm{H} 1$ analyzes metrification on the organizational level. A strong MPR (i.e. strong performance orientation) of the HEI is expected to affect the individual academic who will have more metrified publications. $\mathrm{H} 2$ analyzes metrification over time. We assume a general trend towards more metrification in all disciplines and analyze this using three datasets for three points in time (1992, 2007, and 2018). H3 and $\mathrm{H} 4$ analyze whether more established academics differ from academics who are newer in their status position (full professors or non-full professors) or not.

\subsection{Hypothesis 1: Strong Organizational MPR and Individual Publication Outputs}

$\mathrm{H} 1$ analyzes the implicit and explicit metrification autopilot on the organizational level. $\mathrm{H} 1$ assumes that individual academics publish more in a metrified sense (i.e., more journal articles and fewer books, and more peer-reviewed and co-authored publications) if their HEI has a strong MPR compared to academics at HEls with no or weak MPR. In Table 5, we can observe associations between the organizational level of the higher education institution and individual research output. The indicator for strong MPR on the organizational level is the aggregated mean of research performance orientation on the individual level and serves as the explanatory variable here. We find that a strong MPR on the organizational level is associated with a higher number of articles per author (H1a accepted).

\footnotetext{
${ }^{13}$ One small HEI could not be used in the multilevel analysis due to low case numbers.
} 
Table 5: Multilevel analysis: Institutional research performance orientation

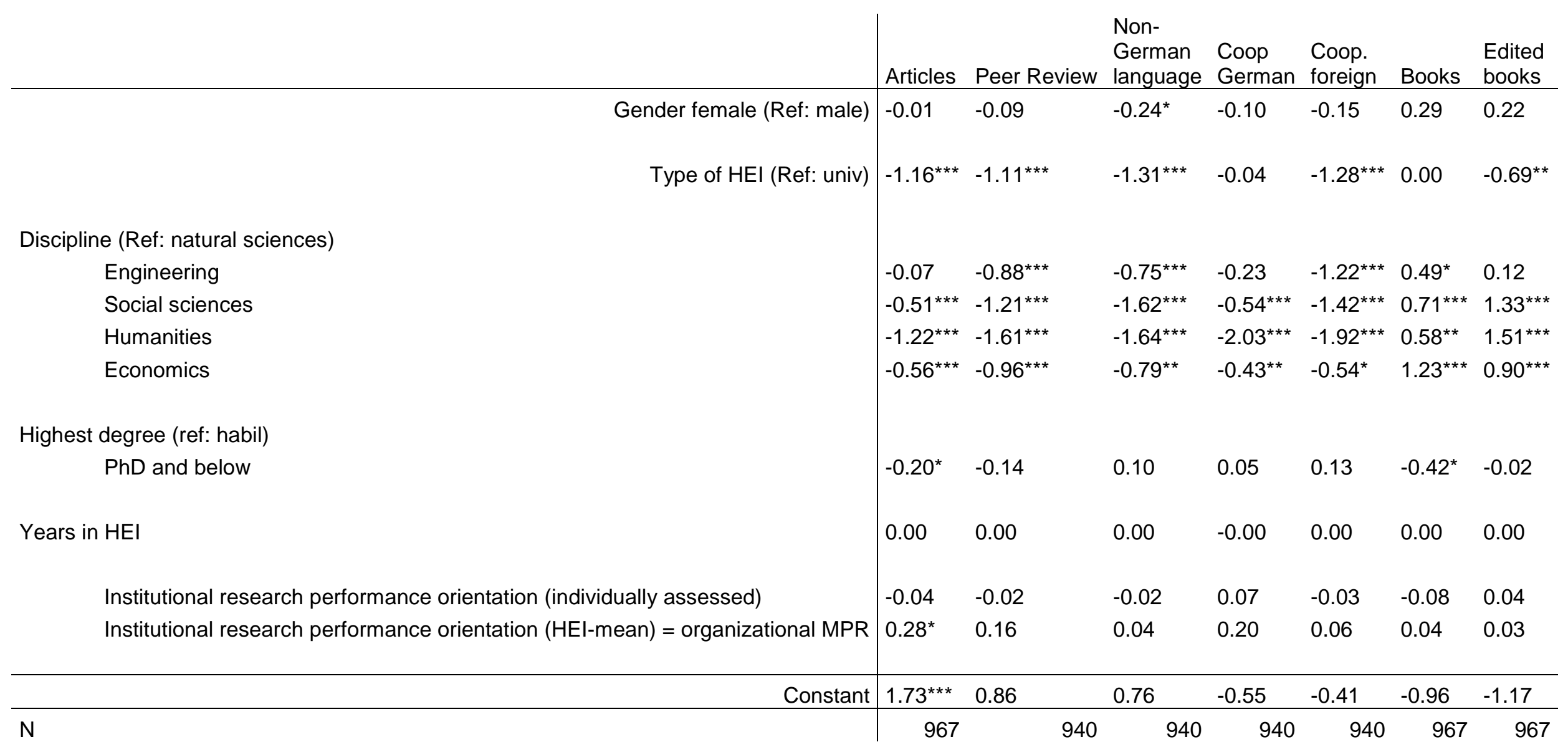

Multilevel models: multilevel negative binomial regression (Articles, Books), multilevel generalized linear models (Non-German language; Coop Foreign; Coop German; Peer Review); ${ }^{*} p<0.05,{ }^{* *} p<0.01,{ }^{* * *} p<0.001$. 
However, all other output variables that are assumed to be higher (peer-reviewed publications; non-German language publications; German and foreign cooperation) are not significantly related to a strong organizational MPR ( $\mathrm{H} 1 \mathrm{~b}, \mathrm{c}$, and $\mathrm{d}$ not accepted). Also book and edited book publishing is not related to organizational MPR and, therefore, we do not find evidence for a correlation between book publishing and organizational MPR (H1e not accepted). Looking at the control variables, the role of disciplines is striking: compared to the reference group of natural sciences, we find significant associations between the disciplines and every publication indicator. Academics in humanities, social sciences, and economics produce fewer metrified publication outputs than those in natural sciences. In sum, research performance orientation in an HEI (organizational MPR) can only be related to higher metrified publication output per academic for the key indicator, namely journal articles. ${ }^{14}$

\subsection{Hypothesis 2: Auto-metrification in Disciplines over time}

$\mathrm{H} 2$ analyzes metrification on the discipline level. $\mathrm{H} 2$ assumes that publications by individual academics in every discipline develop over time (from 1992, 2007 to 2018) towards more metrification, i.e., more journal articles and fewer books, and more peer-reviewed contributions, non-German language publications and co-authored publications. In Table 5, we see the development over time in the number of articles or book chapters published by professors in different academic fields. Taking 1992 as a baseline for the relevant explanatory variable "point in time", the number increased in all disciplines in the years 2007, and in 2018 the coefficients further increased in engineering and social sciences (H2a partly accepted).

As assumed in $\mathrm{H} 2$ (Table 7), the percentage of peer-reviewed publications increased in all disciplines except natural sciences between 2007 and 2018 (H2b accepted). While natural sciences seem to have peaked and no longer show a visible upward trend, academics in other disciplines have published more and more peer-reviewed contributions. The percentage of non-German language publications has increased in the humanities and economics between 2007 and 2018 (Table 7) (H2c partly accepted). We do not find these developments in other disciplines. With regard to the indicator for co-authorship with German researchers, we do not find any significant coefficients (Table 8). But for co-authorship with foreign researchers, we find a positive relation in economics (Table 7). Thus, evidence for increased co-authorship in general is sparse ( $\mathrm{H} 2 \mathrm{~d}$ not accepted). The number of books published per academic has significantly decreased in social sciences and the humanities (and also in the natural sciences) in 2018 compared to 1992 (Table 6).

\footnotetext{
${ }^{14}$ We also conducted a single level analysis for $\mathrm{H} 1$ as a robustness check (table $\mathrm{A} 2$ in annex 2). We find very similar patterns, and the same significant effects for article publications. In addition, we did this analysis for non-full professors at universities as target group. They also show the positive relationship of MPR with articles, and additionally for co-authorship in Germany and co-authorship in foreign countries.
} 
Table 6: Development over time (Articles, books)

\begin{tabular}{|c|c|c|c|c|c|c|c|c|c|c|c|c|c|c|c|c|c|c|c|}
\hline & \multicolumn{6}{|c|}{ Articles } & \multicolumn{6}{|c|}{ Books } & \multicolumn{6}{|c|}{ Edited books } \\
\hline & & All & $\begin{array}{l}\text { Natural } \\
\text { sciences }\end{array}$ & Engin. & $\begin{array}{l}\text { Social } \\
\text { science }\end{array}$ & Huma. & Econ. & All & $\begin{array}{l}\text { Natural } \\
\text { science }\end{array}$ & Engin. & $\begin{array}{l}\text { Social } \\
\text { science }\end{array}$ & Huma. & Econ & All & $\begin{array}{l}\text { Natural } \\
\text { science }\end{array}$ & Engin. & $\begin{array}{l}\text { Social } \\
\text { science }\end{array}$ & Huma. & Econ \\
\hline \multicolumn{20}{|c|}{ Point in time (Ref: 1992) } \\
\hline \multirow{2}{*}{\multicolumn{2}{|c|}{$\begin{array}{l}2007 \\
2018\end{array}$}} & $0.53^{\star \star \star}$ & $0.65^{\star \star \star}$ & ${ }_{*}^{0.67^{* *}}$ & $0.30^{*}$ & $0.52^{\star \star \star}$ & $0.54^{* \star}$ & $-0.23^{*}$ & -0.29 & 0.14 & -0.28 & -0.42 & -0.17 & $0.31^{* *}$ & 0.59 & -0.51 & 0.35 & 0.31 & 0.48 \\
\hline & & $0.50^{* \star *}$ & $0.53^{\star \star \star}$ & $\begin{array}{l}1.01 \times x \\
*\end{array}$ & $0.39^{* * *}$ & $0.33^{\star \star \star}$ & 0.18 & $-0.25^{* *}$ & $-0.41^{*}$ & 0.41 & $-0.64^{\star \star \star}$ & $-0.37^{\star}$ & 0.00 & $0.18^{*}$ & 0.13 & 0.31 & 0.11 & $0.33^{*}$ & -0.10 \\
\hline \multirow{2}{*}{\multicolumn{2}{|c|}{$\begin{array}{l}\text { Gender female (Ref: male) } \\
\qquad \begin{array}{l}\text { Type of HEI } \\
\text { (Ref: univ) }\end{array}\end{array}$}} & $\mid-0.03$ & 0.01 & 0.18 & -0.11 & -0.08 & 0.05 & 0.11 & 0.26 & 0.44 & 0.15 & 0.17 & -0.41 & 0.19 & 0.46 & 0.86 & 0.10 & -0.13 & -0.38 \\
\hline & & $-1.13^{\star \star \star}$ & $-1.37^{* \star \star}$ & ${ }_{*}^{1.63^{* *}}$ & $-0.54^{* \star \star}$ & $-0.39^{* *}$ & $\bar{x}^{1.111^{* *}}$ & -0.02 & 0.23 & ${ }^{-}{ }_{*}^{0.75 *}$ & 0.20 & 0.16 & 0.16 & ${ }_{*}^{0.82^{\star *}}$ & $-1.05^{\star \star}$ & ${ }_{*}^{1} .30^{* *}$ & -0.26 & $0.86^{\star \star \star}$ & -0.21 \\
\hline \multicolumn{20}{|c|}{ Discipline (Ref: natural sciences) } \\
\hline \multirow{6}{*}{$\begin{array}{l}\text { Highest degre } \\
\text { habil) }\end{array}$} & Engineering & $-0.21^{\star \star \star}$ & & & & & & $0.28^{\star}$ & & & & & & -0.03 & & & & & \\
\hline & Social sciences & -0.03 & & & & & & ${ }_{\star}^{0.91^{\star \star}}$ & & & & & & $\begin{array}{l}1.22^{\star *} \\
{ }^{*}\end{array}$ & & & & & \\
\hline & Humanities & $-0.32^{\star \star *}$ & & & & & & ${ }_{\star}^{0.62^{* \star}}$ & & & & & & ${ }_{*}^{1.33^{* \star}}$ & & & & & \\
\hline & Economics & $-0.19^{\star}$ & & & & & & ${ }^{1} .11^{1 *}$ & & & & & & $\begin{array}{l}1.05^{* *} \\
*\end{array}$ & & & & & \\
\hline & & & & & & & & & & & & & & & & & & & \\
\hline & $\mathrm{PhD}$ and below & $-0.22^{\star \star \star}$ & $-0.30^{* *}$ & $-0.36^{*}$ & -0.13 & $-0.31^{\star \star}$ & -0.13 & $0.35^{\star \star}$ & -0.22 & -0.23 & $-0.39^{\star}$ & $0.79^{* \star \star}$ & -0.47 & -0.06 & 0.29 & -0.26 & -0.05 & -0.21 & -0.92 \\
\hline Years in HEl & & 0.00 & 0.00 & $0.01^{*}$ & 0.00 & 0.00 & $-0.02^{*}$ & 0.00 & 0.01 & 0.00 & 0.01 & 0.01 & -0.02 & $0.01^{*}$ & 0.01 & 0.00 & -0.00 & $0.02^{\star}$ & 0.00 \\
\hline Constant & & $2.30^{\star \star *}$ & $2.39^{\star \star \star}$ & $1.98^{* *}$ & $2.23^{* \star \star}$ & $2.05^{\star \star \star}$ & $2.53^{* *}$ & $0.81^{\star *}$ & $-1.02^{\star \star \star}$ & -0.66 & 0.11 & -0.19 & 0.62 & $1.12^{* \star}$ & $-1.33^{\star * \star}$ & -0.69 & 0.24 & 0.10 & 0.41 \\
\hline $\mathrm{N}$ & & 1956 & 622 & 429 & 335 & 386 & 184 & 1956 & 622 & 429 & 335 & 386 & 184 & 1956 & 622 & 429 & 335 & 386 & 184 \\
\hline
\end{tabular}

Negative binomial regressions; ${ }^{*} p<0.05,{ }^{* *} p<0.01,{ }^{* * *} p<0.001$. 
Table 7: Development over time (Peer review, Non-German language)

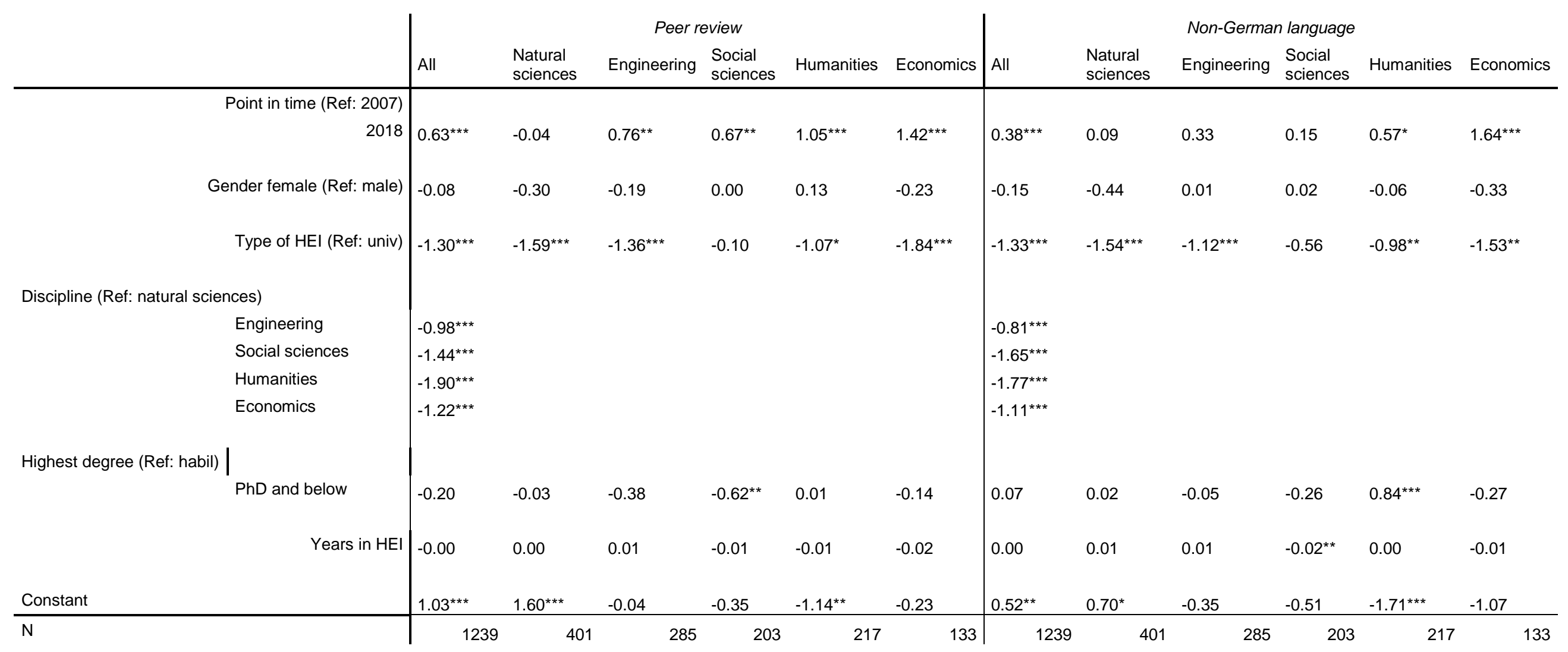

Fractional logit model; ${ }^{*} p<0.05,{ }^{* *} p<0.01,{ }^{* * *} p<0.001$. 
Table 8: Development over time (Co-authorship)

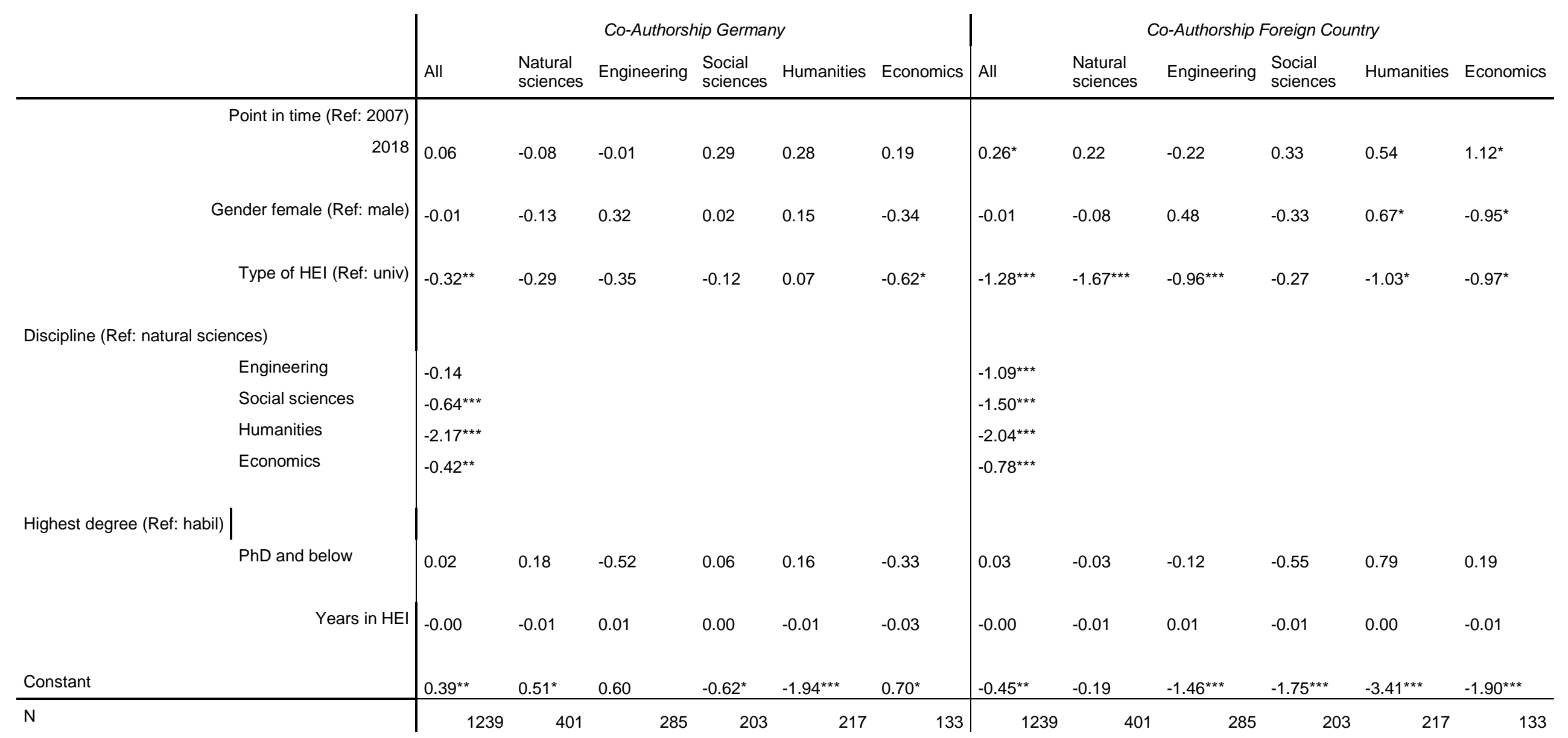

Fractional logit model; * $p<0.05,{ }^{* *} p<0.01,{ }^{* * *} p<0.001$. 
Thus, in these two fields where traditionally books were published, the assumed trend toward fewer books can be observed. At the same time, we do not find much significant evidence on changes in the number of edited books per author in the same two fields (Table 6) (H2e partly accepted). In the humanities, in 2018 academics published more in edited books compared to 1992. With an increase in the number of journal articles and book chapters per author, this development makes sense because the book chapters have to appear in an edited book.

In sum, several but not all indicators point towards the metrification paradigm. Overall, $\mathrm{H} 2 \mathrm{can}$ be accepted. Academics are publishing more articles and especially a higher share of peerreviewed publications. Further, in some disciplines the share published abroad has increased. Books per author have decreased over time in the disciplines where they are generally relevant. However, not all disciplines show the expected trends for all variables.

\subsection{Hypothesis 3: Auto-metrification of full professors}

$\mathrm{H} 3$ addresses the metrification autopilot of full professors in relation to the number of years they have held this status. Since newer academics are confronted by MPR-norms, H3 assumes that academics that are new (0-6 years) to their position as full professor publish more metrified outputs (i.e. more journal articles, peer-reviewed contributions, non-German language publication and co-authored publications, and fewer books) in comparison to more established academics. 'Years in academia in the respective position' serves as an explanatory variable. We conduct the analysis for the 2007 CAP survey and 2018 APIKS survey separately. With regard to articles (Table 9), professors do not show a clear trend related to years as a full professor. However, contradictory to our assumption, more established (13 to 18 years) full professors publish more articles than new full professors (H3a not accepted). Turning to peer-reviewed publications (Table 9), well-established full professors (19 years and longer) publish less than new full professors (both in 2007 and 2018) (H3b partly accepted).

With regard to non-German language publications (Table 10), we do not find a clear trend for full professors. They seem to publish less when they are more established, but most coefficients are not significant ( $\mathrm{H} 3 \mathrm{c}$ not accepted). Looking at collaboration with German academics (Table 10), we do not find a clear relationship. Turning to collaborations with foreign academics (Table 10), in 2018 the oldest category of well-established professors (19 years and over) publish less often with foreign researchers compared to new professors. Patterns are similar in 2007 but not significant (H3d not accepted). 
Table 9: Publication output: newer vs. established full professors (Articles, Peer-reviewed publications)

\begin{tabular}{|c|c|c|c|c|c|}
\hline & & $\begin{array}{l}\text { Articles } \\
\text { CAP }\end{array}$ & APIKS & $\begin{array}{l}\text { Peer } \\
\text { Review } \\
\text { CAP }\end{array}$ & APIKS \\
\hline & Gender female (Ref: male) & -0.09 & -0.00 & 0.22 & 0.00 \\
\hline & Type of HEI (Ref: univ) & $-1.02^{* * *}$ & $-1.23^{\star * *}$ & $-1.89^{\star \star *}$ & $-1.21^{* * *}$ \\
\hline \multicolumn{6}{|c|}{ Discipline (Ref: natural sciences) } \\
\hline & Engineering & $-0.67^{\star \star *}$ & $-0.18^{*}$ & $-1.75^{\star \star \star}$ & $-0.88^{* \star *}$ \\
\hline & Social sciences & -0.33 & -0.06 & $-2.28^{\star \star \star}$ & $-1.30^{\star \star \star}$ \\
\hline & Humanities & -0.24 & $-0.36^{\star \star *}$ & $-3.19 * * *$ & $-1.52^{\star * \star}$ \\
\hline & Economics & -0.25 & $-0.36^{\star \star *}$ & $-2.44^{\star \star \star}$ & $-0.98^{\star \star *}$ \\
\hline \multicolumn{6}{|c|}{ Years in position (Ref: 0-6 years) } \\
\hline & (7-12 years) & 0.17 & 0.10 & $-0.76^{\star \star}$ & -0.09 \\
\hline & (13-18 years) & 0.23 & $0.16^{*}$ & -0.51 & -0.04 \\
\hline & (19 or more years) & -0.29 & 0.08 & $-0.84^{*}$ & $-0.39^{*}$ \\
\hline Constant & & $2.87^{\star \star \star}$ & $2.72^{\star \star \star}$ & $2.11^{* \star \star}$ & $1.44^{* * *}$ \\
\hline$N$ & & 29 & 875 & 271 & 854 \\
\hline
\end{tabular}

Negative binomial regression (Articles), fractional logit models (Peer Review); ${ }^{*} p<0.05,{ }^{* *} p<0.01,{ }^{* \star *} p<0.001$. 
Table 10: Publication output: newer vs. established full professors (Non-German language, Co-author Germany, Co-author foreign country)

\begin{tabular}{|c|c|c|c|c|c|c|c|}
\hline & \multicolumn{2}{|c|}{ Non-German language } & \multicolumn{2}{|c|}{ Co-author Germany } & \multicolumn{2}{|c|}{ Co-author foreign country } \\
\hline & & CAP & APIKS & CAP & APIKS & CAP & APIKS \\
\hline & Gender female (Ref: male) & 0.59 & -0.21 & 0.07 & 0.03 & $0.75^{\star}$ & -0.05 \\
\hline & Type of HEI (Ref: univ) & $-1.33^{\star \star \star}$ & $-1.26^{\star * *}$ & $-0.69^{* \star}$ & -0.11 & $-1.13^{\star \star *}$ & $-1.41^{* \star *}$ \\
\hline \multicolumn{8}{|c|}{ Discipline (Ref: natural sciences) } \\
\hline & Engineering & $-1.16^{* * *}$ & $-0.85^{\star \star \star}$ & -0.03 & -0.13 & $-1.04^{\star * \star}$ & $-1.10^{* * *}$ \\
\hline & Social sciences & $-1.90^{* * *}$ & $-1.71^{\star * *}$ & $-0.98^{* * *}$ & $-0.56^{* * *}$ & $-1.78^{* * *}$ & $-1.51^{* \star \star}$ \\
\hline & Humanities & $-2.58^{\star \star *}$ & $-1.57^{\star \star \star}$ & $-2.52^{\star \star \star}$ & $-1.98^{* * *}$ & $-2.74^{\star \star \star}$ & $-1.94^{\star \star \star}$ \\
\hline & Economics & $-2.34^{* * *}$ & $-0.85^{\star \star \star}$ & -0.34 & $-0.41^{*}$ & $-1.56^{\star \star \star}$ & $-0.57^{\star \star}$ \\
\hline \multicolumn{8}{|c|}{ Years in position (Ref: $0-6$ years) } \\
\hline & (7-12 years) & $-0.64^{*}$ & -0.10 & -0.21 & 0.09 & -0.45 & -0.27 \\
\hline & (13-18 years) & -0.29 & -0.03 & 0.31 & 0.18 & -0.14 & -0.27 \\
\hline & (19 or more years) & -0.46 & -0.35 & -0.16 & -0.28 & -0.48 & $-0.47^{*}$ \\
\hline Constant & & $1.11^{\star \star \star}$ & $1.01^{* * *}$ & $0.55^{*}$ & $0.29^{*}$ & -0.32 & -0.00 \\
\hline$N$ & & 271 & 854 & 271 & 854 & 271 & 854 \\
\hline
\end{tabular}

Fractional logit models ${ }^{*} p<0.05,{ }^{* *} p<0.01,{ }^{* * *} p<0.001$ 
Table 11: Publication output: newer vs. established full professors (Books, Edited books)

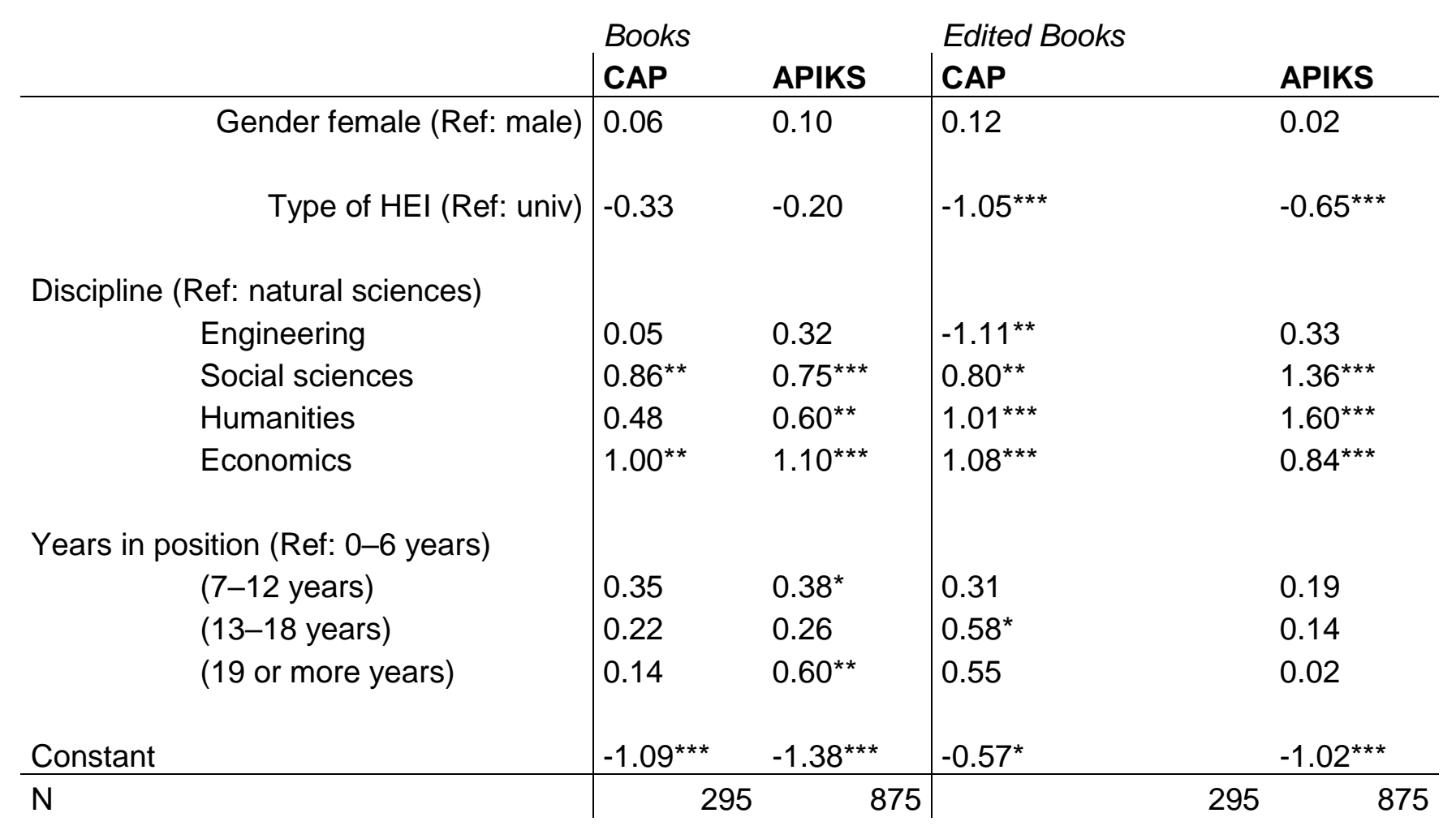

Negative binomial regression; ${ }^{*} p<0.05,{ }^{* *} p<0.01,{ }^{* * *} p<0.001$ 
Regarding books (Table 11), we find no significant associations for full professors in CAP 2007. In APIKS 2018, we see that more established full professors (7-12 years) publish more than full professors who have been in their position for 0 to 6 years. Regarding edited books (Table 11), we find in CAP 2007 that more established full professors (7-12 years) publish more than new full professors (0-6 years). In APIKS 2018, we do not find a relationship. Full professors do not differ significantly in publishing edited books with regard to years in their position $(\mathrm{H} 3 \mathrm{e}$ partly accepted).

In sum, in 2018 we see that among full professors only the well-established (the group '19 years and more') do publish slightly fewer metrified outputs. They have fewer peer-reviewed publications, publish less in collaboration with academics from a foreign country and do publish more books. This is in line with our metrification hypothesis that more established full professors have fewer metrified publication outputs in comparison to new full professors (0-6 years) who are directly socialized in the socio-calculative valuation, evaluation and valorization environment. However, since not all publication types show this differentiation (especially articles) according to year groups, the hypotheses can only be partly accepted.

\subsection{Hypothesis 4: Auto-metrification of non-full professors}

$\mathrm{H} 4$ addresses auto-metrification on the individual level for non-full professors. Just as $\mathrm{H} 3, \mathrm{H} 4$ assumes that academics who are new to their position (here: non-full professors) have more metrified publication outputs (i.e., more journal articles, peer-reviewed contributions, nonGerman language publications and co-authored publications, and fewer books) in comparison to more established academics, since newer academics are socialized into the metrified, sociocalculative valuation, evaluation and valorization environment. Considering the PhD phase as a learning phase, in $\mathrm{H} 4$, the post-doc (and Habilitation) group (7-12 years) is assumed to publish the most metrified outputs. 'Years in academia in the respective position' serves as an explanatory variable here. We analyze the years 2007 (CAP) and 2018 (APIKS) separately. With regard to articles (Table 12), non-full professors publish fewer articles in their starting phase (0-6 years) than in the post-doc phase (7-12 years), both in CAP 2007 and APIKS 2018. However, in APIKS 2018 the most established cohort (13 years and more) of non-full professors produces even more metrified publication outputs than the reference category of post-docs. This result contradicts our assumption in $\mathrm{H} 4$ ( $\mathrm{H} 4 \mathrm{a}$ not accepted). With regard to peer-reviewed publications, we see that academics in their PhD phase (0-6 years) published less than academics in the post-doc phase (7-12 years) in 2018 (APIKS); for CAP 2007 this expectation was also confirmed but is not significant. However, we find no difference between the most established group (13 years and more) and the post-doc group (7-12 years) (H4b not accepted). 
Table 12: Publication output: newer vs. established non-full professors (Articles, Peer-reviewed publications)

\begin{tabular}{|c|c|c|c|c|c|}
\hline & & $\begin{array}{l}\text { Articles } \\
\text { CAP }\end{array}$ & APIKS & $\begin{array}{l}\text { Peer } \\
\text { Review } \\
\text { CAP }\end{array}$ & APIKS \\
\hline & Gender female (Ref: male) & -0.09 & $-0.20 * \star \star$ & -0.57 & -0.09 \\
\hline & Type of HEI (Ref: univ) & $-1.34^{*}$ & $-0.50^{* * *}$ & $-2.12^{*}$ & $-0.81^{* * *}$ \\
\hline \multicolumn{6}{|c|}{ Discipline (Ref: natural sciences) } \\
\hline & Engineering & $-1.00^{\star * *}$ & $-0.51^{* \star *}$ & $-1.39^{* * *}$ & $-0.96^{\star * *}$ \\
\hline & Social sciences & 0.17 & -0.03 & $-1.34^{* * *}$ & $-1.01^{* * *}$ \\
\hline & Humanities & $0.68^{* *}$ & 0.01 & $-1.77^{* * *}$ & $-1.51^{* \star *}$ \\
\hline & Economics & -0.05 & $-0.47^{\star \star *}$ & -0.69 & $-0.85^{\star \star *}$ \\
\hline & $\begin{array}{l}\text { Part-time (Ref: Full-time) } \\
\text { Fixed term (Ref: }\end{array}$ & $-0.74^{\star \star \star}$ & $-0.32^{* \star *}$ & $-0.91^{* *}$ & $-0.44^{\star \star *}$ \\
\hline Contract & Permanent) & -0.21 & $-0.18^{\star *}$ & -0.12 & 0.13 \\
\hline \multirow{2}{*}{\multicolumn{2}{|c|}{$\begin{array}{r}\text { Years in position ( } 0-6 \text { years) } \\
\text { (Ref: } 7-12 \text { years) } \\
\text { (13 or more years) }\end{array}$}} & $-0.49^{* *}$ & $-0.65^{\star * *}$ & -0.15 & $-0.31^{* * *}$ \\
\hline & & -0.21 & $0.14^{*}$ & -0.15 & -0.02 \\
\hline \multicolumn{2}{|l|}{ Constant } & $2.24^{\star \star \star}$ & $2.19^{* \star *}$ & $1.14^{* *}$ & $1.09^{\star * *}$ \\
\hline \multicolumn{2}{|l|}{$N$} & 24 & 3008 & 230 & 2837 \\
\hline
\end{tabular}

Negative binomial regression (Articles/book chapters), fractional logit models (Peer Review); $p<0.05,{ }^{* *} p<0.01,{ }^{* \star *} p<0.001$. 
Table 13: Publication output: newer vs. established non-full professors (Non-German language, Co-author Germany, Co-author foreign country)

\begin{tabular}{|c|c|c|c|c|c|c|c|}
\hline & \multicolumn{2}{|c|}{ Non-German language } & \multicolumn{2}{|c|}{ Co-author Germany } & \multicolumn{2}{|c|}{ Co-author foreign country } \\
\hline & & CAP & APIKS & CAP & APIKS & CAP & APIKS \\
\hline & Gender female (Ref: male) & 0.21 & -0.13 & 0.45 & 0.01 & 0.23 & 0.13 \\
\hline & Type of HEI (Ref: univ) & -1.76 & $-0.83^{\star * \star}$ & -0.03 & $-0.37^{\star \star}$ & 0.49 & $-0.99^{* * *}$ \\
\hline \multicolumn{8}{|c|}{ Discipline (Ref: natural sciences) } \\
\hline & Engineering & $-1.29^{\star \star \star}$ & $-0.65^{\star \star \star}$ & -0.38 & 0.00 & $-1.23^{\star \star \star}$ & $-1.23^{* * *}$ \\
\hline & Social sciences & $-2.83^{\star \star \star}$ & $-1.13^{\star \star \star}$ & $-1.15^{\star \star \star}$ & $-0.47^{\star \star *}$ & $-2.09^{\star \star \star}$ & $-1.39^{* * *}$ \\
\hline & Humanities & $-1.98^{\star * \star}$ & $-1.46^{\star \star *}$ & $-3.02^{\star \star *}$ & $-1.92^{\star \star *}$ & $-2.07^{\star *}$ & $-2.02^{\star * *}$ \\
\hline & Economics & $-1.95^{\star \star \star}$ & $-0.65^{\star \star \star}$ & -0.30 & -0.29 & $-1.24^{*}$ & $-1.13^{* * *}$ \\
\hline & $\begin{array}{l}\text { Part-time (Ref: Full-time) } \\
\text { Fixed term (Ref: }\end{array}$ & -0.52 & $-0.38^{* * *}$ & 0.07 & 0.05 & 0.37 & $-0.46^{\star \star \star}$ \\
\hline Contract & Permanent) & 0.37 & $0.41^{* * *}$ & 0.17 & 0.09 & -0.27 & $0.51^{\star \star \star}$ \\
\hline \multirow{2}{*}{\multicolumn{2}{|c|}{$\begin{array}{r}\text { Years in position (0-6 years) } \\
\text { (Ref: } 7-12 \text { years) } \\
\text { (13 or more years) }\end{array}$}} & 0.10 & $-0.36^{\star * *}$ & -0.16 & -0.01 & 0.00 & $-0.44^{\star \star *}$ \\
\hline & & 0.11 & 0.22 & -0.14 & 0.02 & 0.53 & $0.39^{\star \star \star}$ \\
\hline \multirow{2}{*}{\multicolumn{2}{|c|}{$\begin{array}{l}\text { Constant } \\
\mathrm{N}\end{array}$}} & 0.26 & 0.18 & 0.62 & $0.53^{* * *}$ & $-0.90^{*}$ & $-0.96^{\star \star *}$ \\
\hline & & 230 & 2837 & 230 & 2837 & 230 & 2837 \\
\hline
\end{tabular}

Fractional logit models ${ }^{*} p<0.05,{ }^{* *} p<0.01,{ }^{* * *} p<0.001$ 
Table 14: Publication output: newer vs. established non-full professors (Books, Edited books)

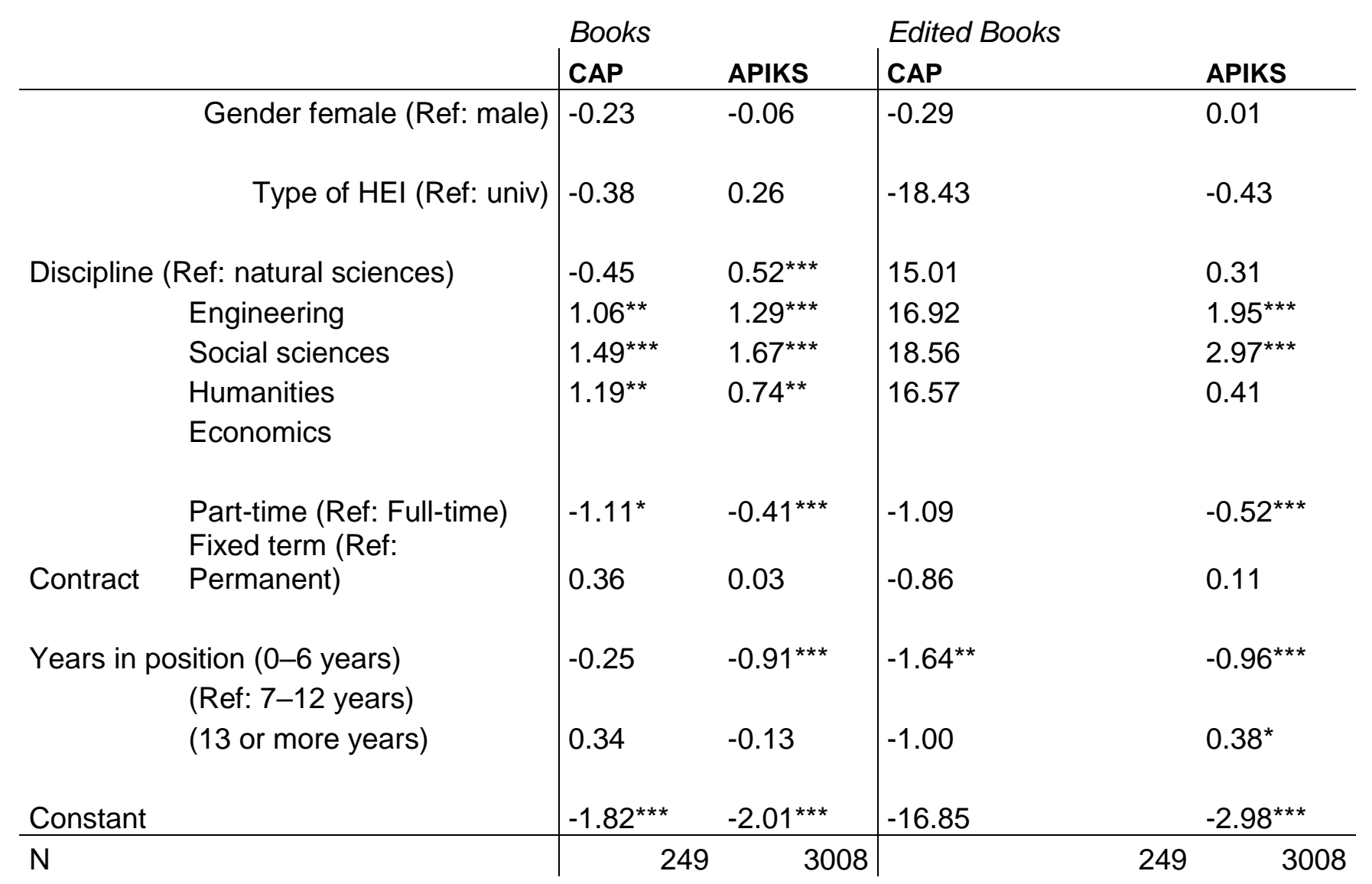

Negative binomial regression; * $\mathrm{p}<0.05,{ }^{* *} \mathrm{p}<0.01,{ }^{* \star *} \mathrm{p}<0.001$. 
With regard to non-German language publications (Table 13), we find that non-full professors publish significantly less in the PhD phase (0-6 years) in comparison to more established academics (post-doc) in APIKS 2018. We do not find differences between the latter group and the most established group of non-full professors (13 years and more) ( $\mathrm{H} 4 \mathrm{c}$ not accepted). Looking at collaboration with German researchers, we do not find any significant associations for any of the three groups. Concerning collaborations with foreign researchers, academics in the post-doc phase (7-12 years) publish more than academics in their PhD phase (0-6 years) in APIKS as expected, but the most established non-full-professors (13 years and more) publish even more, contradicting our expectations ( $\mathrm{H} 4 \mathrm{~d}$ not accepted). Regarding books (Table 14), non-full professors publish more books in the post-doc phase (7-12 years) than in the PhD phase (0-6 years) (in CAP not significantly, and with a smaller coefficient). More established non-full professors (13 years and more) do not differ from the non-full professors in the post-doc phase (7-12 years), which contradicts the expectation of H4. Both in CAP 2007 and APIKS 2018, non-full professors publish more edited books (Table 13) in the post-doc phase (7-12 years) than in the PhD phase. Again, in APIKS 2018 the more established nonfull professors (13 years and more) publish even more edited books ( $\mathrm{H} 4 \mathrm{e}$ partly accepted). This is in line with the $\mathrm{H} 4$ expectation since the most established non-full professors (13 years and more) were socialized pre-metrification.

Being in the post-doc phase is clearly associated with higher publication outputs in comparison to the PhD phase. In APIKS 2018, six out of seven indicators show this association (only publishing in cooperation with Germans is an exception). This applies to both metrified publication outputs (articles, peer review, publishing in foreign country, cooperation with foreign researcher) as well as generally non-metrified outputs (books and edited books). However, the expectation was wrong that non-professorial academics in the post-doc phase publish more metrified outputs in comparison to the most established academics (13 years and more). ${ }^{15}$ Accordingly, $\mathrm{H} 4$ cannot be accepted. Results indicate that longer establishment is associated with more publications in general for non-full professors. In CAP 2007, the associations between time in status position and publication outputs are much less clear. This can be due to two factors: First, CAP case numbers are lower than APIKS case numbers. Therefore, CAP 2007 results might be less well estimated. Second, the CAP 2007 survey marks the institutionalization of the socio-calculative valuation, evaluation and valorization environment, and, therefore the trends are much more visible in 2018 (APIKS) as the metrification paradigm has become more important over time.

\footnotetext{
15 A further analysis (not reported) for the category "13 years or more" only was expected to reveal whether fixed-term non-full professors differ from permanently employed non-full professors or not. However, there was only a relationship for non-German language publications, and cooperation with foreign country (with fixed-term employees publishing more than permanently employed).
} 


\section{Discussion of Results and Conclusions}

In this study we analyzed the individual publication outputs of academics in Germany over the last three decades. We theoretically assumed that we can observe the development of MPR within the academic profession. Contrary to strong evaluation states (Whitley 2007), in German higher education and science neither academics nor HEls are forced by law to conduct metrified evaluations of publication outputs. Therefore, we assumed that the German academic profession is operating on metrification autopilot, which we tested in four hypotheses. The four hypotheses addressed the individual level, differentiating full professors $(\mathrm{H} 3)$ and non-full professors $(\mathrm{H} 4)$, the disciplines on the systems level $(\mathrm{H} 2)$ and the organizational level of HEls $(\mathrm{H} 1)$. Summarizing the above empirical results, we see the metrification autopilot as a trend at work within the German academic profession. Our results show that the metrification autopilot was already working at the time of the CAP 2007 survey and that MPR seems to be in a consolidation phase at the time of the APIKS 2018 survey.

The clearest empirical evidence of the metrification trend can be found at the level of disciplines. Based on the theoretical assumption of auto-metrification through disciplinary trickle-down processes of comparison and adaption (Rijcke et al. 2016) and on previous research (e.g., Cole 1983; Heintz and Werron 2011) we assumed in $\mathrm{H} 2$ that academics in all disciplines now tend to the publication norms of the natural sciences. In general, this hypothesis can be accepted. Overall, academics are publishing more articles from Carnegie 1992 via CAP 2007 to APIKS 2018, and especially peer-reviewed contributions have increased in all disciplines. While publications in co-authorship are stable, publishing abroad has increased in some disciplines, and the number of books published per academic has decreased in humanities and social sciences. The decreasing number of books in the social sciences and the humanities is interpreted as a sign of the impact of metrification. However, the book is not disappearing, but the tradition of publishing books in these fields can be observed as becoming weaker. We have to keep in mind that books are not devaluated in the German academic system as the APIKS 2018 results for $\mathrm{H} 3$ show. In spite of the metrification trend, books are still very common, for example the vast majority of $\mathrm{PhD}$ theses are published as a monograph (GFSO 2016a), and books are institutionally rewarded (Table 1).

The rise in the number of articles and peer-reviewed publications indicates a tendency toward the MPR hypothesis as this is assumed to be the "path to success" (Karpik 2011, p. 73) and now forms the core of "normal science" (Karpik 2011, p. 83) that affects all disciplines. Further, the increase in publishing abroad means that academics in Germany are publishing in English, thus increasing their visibility, which is crucial in international competition (Mau 2018). Regarding the changes in publication behavior, bibliometric studies focusing on Web of Science publications came to similar results, finding that German academics increasingly publish with US publishers (e.g., Michels and Schmoch 2014). However, in our study this is 
not the case in all disciplines (not in social sciences and engineering). Research in these disciplines still focuses on local problems (social sciences: Dyachenko 2014; engineering: Kaltenbrunner 2018), which also contributes to the German academic identity construction, for example of the German engineer. Surprisingly, in our data we do not find evidence for the increase in co-authorship that can be found in studies from other countries (Henriksen 2016; Ossenblok et al. 2014). One possible interpretation of our finding is that the peak in collaboration was already reached during the CAP 2007 survey. Please be aware that our analysis only shows correlations and not causal effects.

The diversity in disciplinary publication traditions still seems to be stronger than organizational MPR practices. However, in $\mathrm{H} 1$ we found a significant correlation between strong MPR on the organizational level and a higher number of articles per academic. We interpret the robust finding concerning journal articles - the key metrification publication - as the organizational level becoming a driver for auto-metrification in addition to the discipline level. Acknowledging that metrification research is rather new for German higher education and science studies (Gläser and Laudel 2019), we did an exploratory analysis triggered by previous findings, for example, from Allison and Long (1990) and Smeby and Try (2005), who found that the department has an effect on individual research output. To further explore this correlation we analyzed the publication outputs of the contrasting examples of natural sciences (hard pure; dominant: peer-review journal publication; $\mathrm{H} 1$ ) and the humanities (soft pure; dominant: book

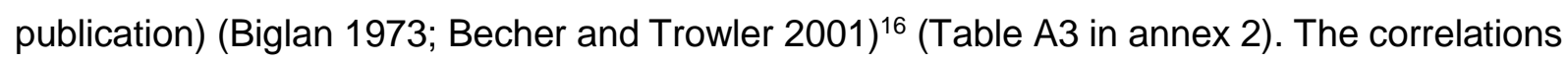
between publication outputs in natural sciences and humanities and organizational MPR orientation are as follows: for articles, organizational MPR is related to higher individual output in the natural sciences but not in the humanities. However, the results regarding peer review can be interpreted as a first indication that academics in the humanities are reactive and are gradually adapting their publication behavior toward the metrified natural sciences criteria, although the humanities traditionally have a very different publication culture, which is in line with findings by Kulczycki et al. (2018) and others.

Initial cautious conclusions about the mechanisms of auto-metrification can be drawn based on the findings of organizational (meso-level) impact on different disciplinary cultures (macrolevel). While organizational MPR in the natural sciences can be regarded as a driver of the metrified publication behavior both at the organizational and disciplinary level, the trend in the humanities seems to be more discipline-driven adaptation processes. The limited impact of the organizational level is shown by other studies about the relative insignificance of MPR for

\footnotetext{
${ }^{16}$ For a comparison of diverse disciplinary cases, contrasting the humanities with the natural sciences is more appropriate than using the social sciences. In Biglan's (1973) terminology the social sciences are in-between the hard pure natural sciences and the soft pure humanities. Becher and Trowler (2001) also stress the connectedness of social sciences to natural sciences with the importance of mathematics, and to humanities with the complex, less readily divisible and local research challenges.
} 
individual professors' salaries (Lange 2007; Wilkesmann and Schmid 2012; for Norway, see Aagaard et al. 2015). In Germany, the relative insignificance of MPR for individual professors' salaries is justified by academic freedom, which limits HEI governance and higher education and science policy exerting too much influence on academics' research, publication, etc. behavior (Gläser 2019; Schimank 2005, 2010). Accordingly, the socio-calculative interlocking of organizational and individual development in HEls via performance-based remuneration and agreement on objectives is less strong than in human resources management in business organizations analyzed by Vormbusch (2012). Thus it seems plausible that organizational MPR is most effective where it connects to the tacit, "embodied knowledge" (Bourdieu 1995) or "bio-politics" (Foucault 2008, 2010) of a metrified publication culture, such as in the natural sciences. In other disciplinary fields MPR becomes effective through auto-metrification and peer pressure (see also Flink and Simon 2014). Future research with larger datasets and comparisons between countries with a weak and a strong metric culture are needed to elaborate the mechanisms further, for example in relation to accountability (e.g., Hammarfelt and de Rijcke 2015) and the impact of university ranking schemes (e.g., Gu and Blackmore 2017).

On the individual level (micro-level), in $\mathrm{H} 3$ we analyzed whether academics who are new in their status position of full professor in particular are leaning toward the norms of metrification. Looking at newer full professors, we do not find much evidence for this assumption for APIKS 2018. Altogether the results are rather mixed, and in comparison to CAP 2007, the distributions of metrified publication outputs in APIKS 2018 are less clear. In comparison to new full professors (0-6 years), full professors who have been in their position for 13-18 years publish significantly more articles, but full professor who have held this position for more than 19 years publish significantly fewer peer-reviewed publications. This is only partly in line with our assumption of newer academics sticking more closely to metrification norms.

In comparison to newer full professors, well-established full professors (19 years and more) publish significantly more books, irrespective of the decreasing number of book publications over time shown in the APIKS 2018 survey (as seen in H3). Of the traditional explanations (Kyvik and Olsen 2008), the explanation that well-established professors might belong to a different academic generation with a different research culture (Kwiek 2015; Marquina et al. 2015), in which peer-reviewed articles were not the only recognized publication output, might still be applicable. However, well-established full professors (19 years and more) and established full professors (13-18 years) also produce articles and to a lesser extent peerreviewed publications. Generally, the relations between years as a full professor and all publication outputs are statistically rather weak for (well-)established full professors (both in APIKS 2018 and CAP 2007), which is in line with previous research (e.g., Stroebe 2010). In contrast to $\mathrm{H} 3$, we have to conclude that the generalization of MPR seems to work as an 
equalizer within the group of full professors. Accordingly, the socio-calculative valuation, evaluation and valorization environment (Vatin 2013; Vormbusch 2012) creates group pressure and slowly but steadily limits professional autonomy of individual academics. We interpret these findings as the construction of the socio-calculative valuation, evaluation and valorization environment by the academic "oligarchy" (Brennan 2010; Clark 1983; Pusser 2008), which aims for sustaining previously more implicit reputation-gain and performance recognition by means of commensuration (Espeland and Sauder 2007) and metrification. According to this interpretation, the academic oligarchy in particular and full professors on metrification autopilot in general, seem to foster auto-metrification to explicitly define their superior position within the academic profession. However, we find differences between disciplines. In the humanities the academic oligarchy of the discipline seems to be the driver of auto-metrification. In natural sciences the metrification autopilot seems to be part of the academic culture of both the disciplinary and the institutional (i.e., presidents, members of academic senates and the DFG) academic oligarchy, which is supported by academics having reached the ranks of a full professor.

In contrast to full professors, for non-full professors we find a correlation between years in a non-full professor position and metrified publication output patterns (H4). Most interesting are the findings that in the group of non-full professors, academics who have been in this status position for 13 years and more publish the most metrified and non-metrified publication outputs. ${ }^{17}$ One explanation could be self-selection among academics and weak performers who have left a specific HEl or academia in general after the post-doc phase (see also Balsmeier and Pellens 2014). Another explanation for the empirical findings are that non-full professor academics who have been in this status position for 13 years and more have passed the average age of about 41 years ${ }^{18}$ for accessing a full professorship, and, therefore, invest more in (metrified) publication outputs to improve their chances of becoming a full professor (see also Jungbauer-Gans and Gross 2013). In addition to status seeking and career aspirations, the correlation between (metrified) publication outputs and time in the current position could be interpreted as a learning effect: Academics who have been in the system longer have learnt the rules and have a clear picture of what is rewarded in science (Fochler et al. 2016). Of course, more established non-professorial academics also have more

\footnotetext{
17 About $50 \%$ of the non-full professor group 13 years and more has a fixed-term contract. However, the contract has no influence on metrified publication outputs. In comparison to those on permanent contracts, they produce more non-German language publications and cooperate more often with academics outside Germany.

${ }^{18}$ The average age median for obtaining a university master's degree is about 26 years for females and almost 27 years for males (GFSO 2018b, p. 25). Adding the 12 years for academic qualification as a pre- and post-doctoral academic (Wissenschaftszeitvertragsgesetz 2016) the cumulative age would be about 40 years for females and 41 years for males, which is the median (40 years) and mean (40 years) according to the GFSO (2018b, p. 279).
} 
experience and further qualifications to be able to do research suitable for metrified publication outputs in the form of journal articles and peer-reviewed publications.

Compared to the group of post-doc academics, PhD candidates publish fewer articles and less often in peer-reviewed journals. Accordingly, producing metrified publication output can be interpreted as successful socialization into the academic profession, which takes at least six years and a PhD. This finding strongly questions the merit of passing $\mathrm{PhD}$ regulations that force $\mathrm{PhD}$ candidates to publish journal articles, especially when the $\mathrm{PhD}$ regulations specify that the journal articles have to be single authored, in English and accepted for publication in an indexed journal (Schneijderberg 2018). The paper-based dissertation requirements to publish in $\mathrm{S}(\mathrm{S}) \mathrm{Cl}$-indexed journals and the adherence to journal ranking lists, for example in business, management and economics (Önder and Schweitzer 2017), pushes pre-doctoral academics to embody socio-calculative valuation, evaluation and valorization practices and that only metrified publication outputs "count". Mau (2018, p. 234) describes this symbolic order of the metrical We as follows: "Only those willing to be counted, count as part of the community" (authors' translation).

Summarizing the above empirical results, we see the metrification autopilot as a trend at work within the German academic profession. Contextualizing the above results with the concept elaborated in section 2, in the weak evaluation state of Germany, the introduction and consolidation of MPR is pushed by the academic oligarchy, for example through the introduction of the W-remuneration and the Excellence Initiative. Especially the Excellence Initiative is a powerful driver of auto-metrification, and, therefore, leads to more stratification both among German HEls and academics (see also DFG 2013; IECEEI 2016; Schubert et al. 2017). The Excellence Initiative - as a joint venture between the academic oligarchy organized in the DFG and the German Science Council (Wissenschaftsrat) in social partnership with the German state(s) - is a strong driver for making MPR sustainable on the HEI level and for further pushing auto-metrification on the level of individual academics, both for those academics aspiring to become full professors (status seekers) and those academics who are already full professors (status keepers). Based on our results we can conclude that the influence of the academic oligarchy - in this case primarily as HEI leadership - is less strong on the organizational level and has a much stronger influence via the disciplinary and individual levels.

Accordingly, not the formal, i.e., university but the informal "interlocking" (Vormbusch 2012, p. 167) of organizational, i.e., community and individual academics' development seems to be still prevalent in Germany. On the individual level, the academic oligarchy can influence autometrification because of the status hierarchy and personal dependencies, for example of PhDs and post-docs aspiring for a professorship. The analyzed differences in publication behavior of different career stages of non-full professors show that metrification is higher, the closer the 
academics are to a professorship. So the normative power of metrics set by the academic oligarchy becomes not only effective through organizational MPR, but to a stronger extent through the expected benefit of metrified publication for increasing an individual's chances of attaining tenure. The social valuation expressed by the colleagues' symbolic call for a professorship means a reflexive attribution of meaning to the originally calculative, technical evaluation and valorization process (Vormbusch 2012), for example publishing in journals with high impact factor (Larivière and Sugimori 2019). Accordingly, the metrification autopilot seems driven by the (metrified) publication-based reputation-gain and career aspirations in the sociocalculative valuation, evaluation and valorization environment.

Less direct and even more implicitly driving academics' socio-calculative valuation, evaluation and valorization behavior seems the influence of the academic oligarchy in the disciplinary communities. The natural sciences metrification paradigm of peer-reviewed publications in indexed journals is the most salient example of how auto-metrification norms and status (reputation) security are constructing the academic identity in a socio-calculative valuation, evaluation and valorization environment. So academics co-construct MPR and make it part of academics' socialization and identity politics (Henkel, 2005; Schneijderberg 2018). In a more abstract sense, metrics are just a numerical expression of reputation and status, which are key currencies of the academic profession (e.g., Clark 1983; Merton 1968; Münch 2010). Further research could take a closer look at the trickle-down (full professors and academic oligarchy) and trickle-up (newer academics both in full professor and non-full professor status positions), i.e., the co-evolution of the auto-metrification mechanisms during the institutionalization process of MPR.

\section{References}

Aagaard, K., Bloch, C., \& Schneider, J.W. (2015). Impacts of performance-based research funding systems: The case of the Norwegian Publication Indicator. Research Evaluation, 24(2), 106-117.

Abramo, G., D'Angelo, C.A., Cicero, T., et al. (2012). What is the appropriate length of the publication period over which to assess research performance? Scientometrics, 93(3), 10051017.

Alexander von Humboldt Stiftung. (2008). Publikationsverhalten in unterschiedlichen wissenschaftlichen Disziplinen: Beiträge zur Beurteilung von Forschungsleistungen. Berlin. Altbach, P.G. (ed.) (1996). The International Academic Profession: Portraits of Fourteen Countries. Princeton: Carnegie Foundation for the Advancement of Teaching.

Allison, P.D., \& Long, J.S. (1990). Departmental Effects on Scientific Productivity. American Sociological Review, 55, 469-478. 
Backes-Gellner, U., \& Schlinghoff, A. (2010). Career Incentives and "Publish or Perish" in German and U.S. Universities. European Education 42(3): 26-52.

Balsmeier, B., \& Pellens, M. (2014). Who makes, who breaks: Which scientists stay in academe? Economics Letters, 122, 229-232.

Becher, T., \& Trowler, P.R. (2001). Academic Tribes and Territories. Intellectual enquiry and the culture of disciplines ( $2^{\text {nd }}$ ed.). Buckingham: Open University Press.

Bentley, P. (2012). Gender differences and factors affecting publication productivity among Australian university academics. Journal of Sociology, 48(1), 85-103.

Biglan, A. (1973). The Characteristics of Subject Matter in Different Academic Areas. Journal of Applied Psychology, 57(3), 195-203.

Bol, T., de Vaan, M., van de Rijt, A., et al. (2018). The Matthew effect in science funding. Proceedings of the National Academy of Sciences, 115(19), 4887-4890.

Bornmann, L. (2011). Scientific peer review. Annual Review of Information Science and Technology 45, 197-245.

Bornmann, L., \& Daniel, H.-D. (2016). Count regression in informetrics. Journal of Informetrics, 10, 29-30.

Bornmann, L., Marx, W., Schier, H., Thor, A., \& Daniel, H.-D., et al. (2010). From black box to white box at open access journals: predictive validity of manuscript reviewing and editorial decisions at Atmospheric Chemistry and Physics. Research Evaluation, 19(2), 105-118.

Bourdieu, P. (1975). The Specifity of the Scientific Field and the Social Conditions of the Progress of Reason. Social Science Information, 14, 19-47.

Bourdieu, P. (1995). Outline of a Theory of Practice. Cambridge: Cambridge University Press.

Boyer, E.L., Altbach, P.G., Whitelaw, M.J., et al. (1994). The Academic Profession: An International Higher Perspective. Princeton, NJ: Carnegie Foundation for the Advancement of Teaching.

Bracht, O. (2008). Methodenbericht der Befragung Changing Academic Profession (CAP) 2007. Unpublished Manuscript. Kassel: INCHER-Kassel.

Brennan, J. (2010). Burton Clark's The Higher Education System: Academic Organization in Cross-National Perspective. London Review of Education, 8(3), 229-237.

Bundesverfassungsgericht. (2016). Beschluss des Ersten Senats vom 17. Februar 2016 - 1 BvL 8/10 - Rn. (1-88).

Butler, L. (2003a). Explaining Australia's Increased Share of ISI Publications - the Effects of a Funding Formula Based on Publication Counts. Research Policy, 32(1), 143-155. 
Butler, L. (2003b). Modifying Publication Practices in Response to Funding Formulas. Research Evaluation, 12(1), 39-46.

BuWiN (2017). Bundesbericht wissenschaftlicher Nachwuchs. Bielefeld: Bertelsmann.

Chadegani, A.A., Salehi, H., Yunus, M.M., Farhadi, H., Fooladi, M., Farhadi, M., et al. (2013). A Comparison Between Two Main Academic Literature Collections: Web of Science and Scopus Databases. Asian Social Science, 9(5), 18-26.

Chi, P.-S. (2015). Changing publication and citation patterns in political science in Germany. Scientometrics, 105(3), 1833-1848.

Choung, J.-Y., \& Hwang, H.-R. (2013). The evolutionary patterns of knowledge production in Korea. Scientometrics, 94(2), 629-650.

Clark, B.R. (1983). The Higher Education System. Academic Organization in Cross-National Perspective. Berkeley, CA: University of California Press.

Cole, S. (1983). The Hierarchy of the Sciences? American Journal of Sociology, 89, 111-139. Cole J.R., \& Cole, S. (1973). Social Stratification in Science. Chicago: University of Chicago Press.

de Rijcke, S., Wouters, P.F., Rushforth, A.D., Franssen. T.P., Hammarfelt, B., et al. (2016). Evaluation practices and effects of indicator use - a literature review. Research Evaluation, 25(2), 161-169.

de Solla Price, D.J. (1963). Little Science, Big Science. New Haven: Yale University Press. De Witte, K., \& López-Torres, L. (2017). Efficiency in Education: A Review of Literature and a Way Forward. Journal of the Operational Research Society 68 (4), 339-363.

Desrosières, A. (1998). The politics of large numbers. A history of statistical reasoning. Cambridge: Harvard University Press.

Desrosières, A. (2000). Measurement and its uses: Harmonization and quality in social statistics. International Statistical Review 68(2), 173-187.

DFG - Deutsche Forschungsgemeinschaft (2013). Excellence Initiative at a Glance. Berlin. Dyachenko, E.L. (2014). Internationalization of academic journals: Is there still a gap between social and natural sciences? Scientometrics, 101(1), 241-255.

Enders, J., \& Teichler, U. (1995a). Der Hochschullehrerberuf im internationalen Vergleich. Ergebnisse einer Befragung über die wissenschaftliche Profession. Bonn: Bundesministerium für Bildung, Wissenschaft, Forschung und Technologie. Enders, J., \& Teichler, U. (1995b). Berufsbild der Lehrenden und Forschenden an Hochschulen. Ergebnisse einer Befragung des wissenschaftlichen Personals an westdeutschen Hochschulen. Bonn: Bundesministerium für Bildung, Wissenschaft, Forschung und Technologie. 
Engels, T.C.E., Ossenblok, T.L.B., Spruyt, E.H.J., et al. (2012). Changing publication patterns in the Social Sciences and Humanities, 2000-2009. Scientometrics, 93(2), 373-390. Espeland, W.N., \& Sauder, M. (2007). Rankings and Reactivity: How Public Measures Recreate Social Worlds. American Journal of Sociology, 113, 1-40.

Espeland, W.N., \& Stevens, M. (2008). A sociology of quantification. European Journal of Sociology, 49(3), 401-436.

Festinger, L. (1954). A theory of social comparison processes. Human Relations, 7(2), 117140.

Flink, T., \& Simon, D. (2014). Erfolg in der Wissenschaft: Von der Ambivalenz klassischer Anerkennung und neuer Leistungsmessung. In D. Hänzi, H. Matthies, \& D. Simon (Eds.), Leviathan Sonderband: Vol. 29. Erfolg: Konstellationen und Paradoxien einer gesellschaftlichen Leitorientierung (1st ed., pp. 123-144). Baden-Baden: Nomos-Verl.-Ges. Foucault, M. 2008. The Birth of Biopolitics: Lectures at the College de France 1978-1979. New York: Palgrave.

Foucault, M. 2010. The Government of Self and Others: Lectures at the Collège de France 1982-1983. New York: Palgrave.

Freidson, E. (2001). Professionalization, the third Logic. Chicago: University of Chicago press.

Frey, B.S. (2003). Publishing as prostitution? Choosing between one's own ideas and academic success. Public Choice 116(1): 205-223.

GFSO - German Federal Statistical Office. (2016a). Promovierende in Deutschland. Wiesbaden.

GFSO - German Federal Statistical Office. (2016b). Wissenschaftliches Personal nach Hochschulen und Fächergruppen 2007 und 2014 (H201 Sonderauswertung). Wiesbaden. GFSO - German Federal Statistical Office. (2018a). Personal an Hochschulen. Wiesbaden. GFSO - German Federal Statistical Office. (2018b). Hochschulen auf einen Blick. Wiesbaden.

Gläser, J. (2017). A fight on epistemological quicksand: Comment on the dispute between van den Besselaar et al. and Butler. Journal of Informetrics, 11(3), 927-932.

Gläser, J. (2019). How can governance change research content? Linking science policy studies to the sociology of science. In D. Simon, S. Kuhlmann, J. Stamm, \& W. Canzler (eds.), Handbook on Science and Public Policy (pp. 419-447). Cheltenham: Elgar.

Gläser J., \& Laudel, G. (2019). Die Unterkomplexität hochschulpolitischer Innovationen. In C. Schubert \& I. Schulz-Schaeffer (eds.), Berliner Schlüssel zur Techniksoziologie (pp. 179204). Wiesbaden: Springer. 
Gralka, S., Wohlrabe, K., Bornmann, L., et al. (2019). How to Measure Research Efficiency in Higher Education? Research Grants vs. Publication Output. Journal of Higher Education Policy and Management, 41(3), 322-341.

Gu, X., \& Blackmore, K. (2017). Quantitative study on Australian academic science. Scientometrics, 113(2), 1009-1035.

Haddow, G., \& Hammarfelt, B. (2019). Quality, impact, and quantification: Indicators and metrics use by social scientists. Journal of the Association for Information Science and Technology, 70(1), 16-26.

Hammarfelt, B., \& de Rijcke, S. (2015). Accountability in context: effects of research evaluation systems on publication practices, disciplinary norms, and individual working routines in the faculty of Arts at Uppsala University. Research Evaluation, 24(1), 63-77.

Hammarfelt, B., \& Rushforth, A.D. (2017). Indicators as judgment devices: An empirical study of citizen bibliometrics in research evaluation. Research Evaluation, 26(3), 169-180.

Hardin, J.W., \& Hilbe, J. M. (2012). Generalized linear models and extensions (Third edition). College Station, Texas: Stata Press.

Heintz, B. (2010). Numerische Differenz. Überlegungen zu einer Soziologie des (quantitativen) Vergleichs. Zeitschrift für Soziologie, 39, 162-181.

Heintz, B. (2016). Wir leben im Zeitalter der Vergleichung. Perspektiven einer Soziologie des Vergleichs. Zeitschrift für Soziologie, 45(5), 305-323.

Heintz, B., \& Werron, T. (2011). Wie ist Globalisierung möglich? Zur Entstehung globaler Vergleichshorizonte am Beispiel von Wissenschaft und Sport. Kölner Zeitschrift für Soziologie und Sozialpsychologie, 63(3), 359-394.

Henkel, M. (2005). Academic identity and autonomy in a changing policy environment. Higher Education, 49, 155-176.

Henriksen, D. (2016). The rise in co-authorship in the social sciences (1980-2013). Scientometrics, 107(2), 455-476.

Henriksen, D. (2018). What factors are associated with increasing co-authorship in the social sciences? A case study of Danish Economics and Political Science. Scientometrics, 114(3), 1395-1421.

Hicks, D., \& Wang, J. (2011). Coverage and overlap of the new social sciences and humanities journal lists. Journal of the American Society for Information Science and Technology, 62(2), 284-294.

Hirschauer, S. (2004). Peer Review Verfahren auf dem Prüfstand: Zum Soziologiedefizit der Wissenschaftsevaluation. Zeitschrift für Soziologie, 33(1), 62-83. 
Hirschauer, S. (2014). How Editors Decide. Oral Communication in Journal Peer Review. Human Studies 38(1): 37-55.

Honneth, A. (2005 [1992]). The Struggle for Recognition: The Moral Grammar of Social Conflicts. Cambridge: Polity Press.

Hopkins, A.L., Jawitz, J.W., McCarty, C., Goldman, A., \& Basu, N.B., et al. (2013). Disparities in publication patterns by gender, race and ethnicity based on a survey of a random sample of authors. Scientometrics, 96(2), 515-534.

Huber, J.C. (1998). Cumulative advantage and success-breeds-success: The value of time pattern analysis. Journal of the American Society for Information Science, 49(5), 471-476. IECEEI - International Expert Commission for the Evaluation of the Excellence Initiative (Internationale Expertenkommission zur Evaluation der Exzellenzinitiative) 2016: Endbericht (final report). http://www.gwk-bonn.de/fileadmin/Papers/Imboden-Bericht-2016.pdf (last accessed: 07.05.2019).

Jacob, A.K., \& Teichler, U. (2011). Der Wandel des Hochschullehrerberufs im internationalen Vergleich: Ergebnisse einer Befragung in den Jahren 2007/08. Bonn and Berlin:

Bundesministerium für Bildung und Forschung.

Jacobs, D., \& Ingwersen, P. (2000). A Bibliometric Study of the Publication Patterns in the Sciences of South African Scholars 1981-96. Scientometrics, 47(1), 75-93.

Jung, J. (2012). Faculty Research Productivity in Hong Kong across Academic Discipline. Higher Education Studies, 2(4).

Jungbauer-Gans, M., \& Gross, C. (2013). Determinants of Success in University Careers: Findings from the German Academic Labor Market. Zeitschrift für Soziologie 42(1): 74-92. Kaltenbrunner, W. (2018). Situated Knowledge Production, International Impact: Changing Publishing Practices in a German Engineering Department. Minerva, 56(3), 283-303.

Karpik, L. (2010). Valuing the unique: The economics of singularities. Princeton: Princeton Univ. Press.

Karpik, L. (2011). What Is the Price of a Scientific Paper? In J. Beckert \& P. Aspers (Eds.), The worth of goods: Valuation and pricing in the economy (pp. 63-85). Oxford, New York: Oxford University Press.

Kauppi, N. (2018). The Global Ranking Game: Narrowing Academic Excellence through Numerical Objectification. Studies in Higher Education, 43(10), 1750-1762

Kehm, B.M. (2006). The German 'Initiative for Excellence' and Rankings. International Higher Education, 44, 20-22.

Klenke, D. (2012). Die Einführung der W-Besoldung: Ihre Entstehung aus zeitgeschichtlicher Perspektive. Forschung \& Lehre, 19(3), 190-193. 
Kogan, M., \& Teichler, U. (2007). Key Challenges to the Academic Profession and its Interface with Management: Some Introductory Thoughts. In M. Kogan \& U. Teichler (eds.), Key Challenges to the Academic Profession (pp. 9-15). Kassel: INCHER-Kassel.

Krücken, G., \& Meier, F. (2006). Turning the University into an Organizational Actor. In G. S. Drori, H. Hwang, \& J.W. Meyer (Eds.), Globalization and organization: World society and organizational change. Oxford, New York: Oxford University Press.

Kuhn, T.S. (1970). The Structure of Scientific Revolutions (2 ${ }^{\text {nd }}$ edition). Chicago: University of Chicago Press.

Kulczycki, E., Engels, T.C.E., Pölönen, J., Bruun, K., Dušková, M., Guns, R., Zuccala, A., et al. (2018). Publication patterns in the social sciences and humanities: evidence from eight European countries. Scientometrics, 116(1), 463-486.

Kwiek, M. (2015). Academic generations and academic work: patterns of attitudes, behaviors, and research productivity of Polish academics after 1989. Studies in Higher Education, 40(8), 1354-1376.

Kwiek, M. (2018). High research productivity in vertically undifferentiated higher education systems: Who are the top performers? Scientometrics, 115(1), 415-462.

Kyvik, S. (2003). Changing trends in publishing behaviour among university faculty, 19802000. Scientometrics, 58(1), 35-48.

Kyvik, S., \& Aksnes, D. W. (2015). Explaining the increase in publication productivity among academic staff: a generational perspective. Studies in Higher Education, 40(8), 1438-1453. Kyvik, S., \& Olsen, T. B. (2008). Does the aging of tenured academic staff affect the research performance of universities? Scientometrics, 76(3), 439-455.

Lamont, M. (2012). Toward a Comparative Sociology of Valuation and Evaluation. Annual Review of Sociology, 38, 201-221.

Lange, S. (2007) The Basic State of Research in Germany: Conditions of Knowledge Production Pre-Evaluation. In: Whitley R., Gläser J. (eds) The Changing Governance of the Sciences. Sociology of the Sciences Yearbook (pp 153-170). Springer, Dordrecht.

Larivière, V., \& Gingras, Y. (2010). The impact factor's Matthew effect: A natural experiment in bibliometrics. Journal of the Association of Information Science Technology, 61(2), 424427.

Larivière, V., \& Sugimoto, C.R. (2019). The Journal Impact Factor: A Brief History, Critique, and Discussion of Adverse Effects. In Glänzel W., Moed H.F., Schmoch U., Thelwall M. (eds.) Springer Handbook of Science and Technology Indicators (pp. 3-24). Cham: Springer. Latour, B., \& Woolgar, S. (1979). Laboratory Life: The Social Construction of Scientific Facts. Beverly Hills: Sage Publications. 
Laudel, G., \& Gläser, J. (2006). Tensions between evaluations and communication practices. Journal of Higher Education Policy and Management, 28(3), 289-295.

Leahey, E. (2007). Not by Productivity Alone: How Visibility and Specialization Contribute to Academic Earnings. American Sociological Review, 72(4), 533-561.

Leydesdorff, L., Bornmann, L., \& Opthof, T., et al. (2019). ha: The Scientist as Chimpanzee or Bonobo. Scientometrics, 118(3), 1163-1166.

Long, J.S., \& Freese, J. (2014). Regression models for categorical dependent variables using Stata ( $3^{\text {rd }}$ edition). College Station: Stata Press.

Lotka, A. (1926). The frequency distribution of scientific productivity. Journal of the Washington Academy of Sciences, 16(12), 317-324.

Lutter, M., \& Schröder, M. (2016). Who becomes a tenured professor, and why? Panel data evidence from German sociology, 1980-2013. Research Policy 45: 999-1013.

Lynn, F.B., Podolny, J.M., Tao, L., et al. (2009). A sociological (de)construction of the relationship between status and quality. American Journal of Sociology, 115(3), 755-804.

Mabe, M., \& Mulligan, A. (2011). What journal authors want: Ten years of results from Elsevier's author feedback programme. New Review of Information Networking, 16, 71-89. Marginson, S. (2003). Higher Education Reform in Australia - an evaluation. In H. Eggins (ed.), Globalisation and Reform in Higher Education (pp. 133-163). Buckingham: SRHE/Open University Press.

Marginson, S. \& Considine, M. (2000). The Enterprise University. Power, Governance and Reinvention in Australia. Cambridge: Cambridge University Press.

Marquina, M., Yuni, J., \& Ferreiro, M., et al. (2015). Generational change in the Argentine academic profession through the analysis of 'life courses'. Studies in Higher Education, 40(8), 1392-1405.

Mason, A. (2003). Meritocracy, Desert, and the Moral Force of Instuitions. In Forms of Justice: Critical Perspectives on David Miller's Political Philosophy. Edited by Daniel A. Bell and Avner de-Shalit, 51-68. Lanham: Rowman and Littlefield.

Mau, S. (2018). Das metrische Wir. Über die Quantifizierung des Sozialen. Frankfurt am Main: Suhrkamp.

McClelland, C.E. (1990). Escape from Freedom? Reflections on German Professionalization, 1870-1933. In R. Torstendahl, \& M. Burrage (eds.), The Formation of Professions: Knowledge, State and Strategy (pp. 97-113). London: Sage.

Merigo, J.M., Blanco-Mesa, F., Gil-Lafuente, A.M., Yager, R.R., et al. (2017): Thirty Years of the International Journal of Intelligent Systems: A Bibliometric Review. International Journal of Intelligent Systems 32: 526-554. 
Merton, R.K. (1957). Priorities in Scientific Discovery: A Chapter in the Sociology of Science. American Sociological Review, 22(5), 635-659.

Merton, R.K. (1968). The Matthew effect in science: The reward and communication systems of science are considered. Science, 159, 56-63.

Michels, C., \& Schmoch, U. (2014). Impact of bibliometric studies on the publication behaviour of authors. Scientometrics, 98(1), 369-385.

Miller, D. (1999). Principles of Social Justice. Cambridge: Harvard University Press.

Miller, P., \& Rose, N. (1990). Governing economic life. Economy and Society, 19(1), 1-31. Moed, H.F. (2008). UK Research Assessment Exercises: Informed Judgments on Research Quality or Quantity? Scientometrics, 74(1), 153-161.

Mulligan, A., Hall, S., Raphael, E., et al. (2013). Peer Review in a Changing World: An International Study Measuring the Attitudes of Researchers. Journal of the American Society for Information Science and Technology 64(1):132-161

Münch, R. (2010). Der Monopolmechanismus in der Wissenschaft. Auf den Schultern von Robert K. Merton. Berliner Journal für Soziologie, 20(3), 341-370.

Musselin, C. (2013). How Peer Review Empowers the Academic Profession and University Managers. Changes in Relationships between the State, Universities and the Professoriate. Research Policy, 42, 1165-1173.

Nicolaisen, J., \& Frandsen, T.F. (2019). Zero impact: a large-scale study of uncitedness. Scientometrics 119, 1227-1254.

Olssen, M., \& Peters, M.A. (2007). Neoliberalism, Higher Education and the Knowledge Economy. From the Free Market to Knowledge Capitalism. Journal of Education Policy 20(3), 313-345.

Önder, A.S., \& Schweitzer, S. (2017). Catching up or falling behind? Promising changes and persistent patterns across cohorts of economics PhDs in German-speaking countries from 1991 to 2008. Scientometrics 110(3), 1297-1331.

Ossenblok, T.L.B., Engels, T.C.E., \& Sivertsen, G., et al. (2012). The representation of the social sciences and humanities in the Web of Science - a comparison of publication patterns and incentive structures in Flanders and Norway (2005-9). Research Evaluation, 21(4), 280 290.

Ossenblok, T.L.B., Verleysen, F.T., \& Engels, T.C.E., et al. (2014). Coauthorship of journal articles and book chapters in the social sciences and humanities (2000-2010). Journal of the Association for Information Science and Technology, 65(5), 882-897. 
Osuna, C., Cruz-Castro, L., Sanz-Menéndez, L., et al. (2011). Overturning some assumptions about the effects of evaluation systems on publication performance. Scientometrics, 86, 575-592.

Papke, L.E., \& Wooldridge, J.M. (1996). Econometric methods for fractional response variables with an application to 401 (k) plan participation rates. Journal of Applied Econometrics, 11, 619-632.

Parsons, T. (1968). Professions. In E. Shils (ed.), International Encyclopedia of the Social Sciences (Vol. 12) (pp. 536-547). New York: The Free Press.

Paulus, F.M., Rademacher, L., Schäfer, T.A.J., Müller-Pinzler, L., Krach, S., et al. (2015). Journal Impact Factor Shapes Scientists' Reward Signal in the Prospect of Publication. PLOS One, https://doi.org/10.1371/journal.pone.0142537.

Petersen, A.M., Jung, W.-S., Yang, J.-S., Stanley, H.E., et al. (2011). Quantitative and empirical demonstration of the Matthew effect in a study of career longevity. Proceedings of the National Academy of Science, 108(1), 18-23.

Power, M. (1999). The Audit Society: Rituals of Verification. Oxford: Oxford University Press.

Pusser, B. (2008). The state, the market and the institutional estate: Revisiting contemporary authority relations in higher education. In J. Smart (ed.), Higher Education: Handbook of Theory and Research (Vol. 23) (pp. 105-139). New York: Agathon.

Puuska, H.-M. (2010). Effects of scholar's gender and professional position on publishing productivity in different publication types. Analysis of a Finnish university. Scientometrics, 82(2), 419-437.

Puuska, H.-M. (2014). Scholarly Publishing Patterns in Finland: A comparison of disciplinary groups. Academic dissertation. Tampere: Tampere University Press.

Qasim, M., (2016): Sustainability and Well-being: A Scientometric and Bibliometric Review of the Literature. Journal of Economic Surveys 31(4), 1035-1061.

Rabe-Hesketh, S., \& Skrondal, A. (2012). Multilevel and longitudinal modeling using stata (3 $3^{\text {rd }}$ edition). A Stata Press publication. College Station, Texas: StataCorp LP.

Saam, N.J., \& Reiter, L. (1999). Lotka's law reconsidered: The evolution of publication and citation distributions in scientific fields. Scientometrics, 44(2), 135-155.

Scott, W.R. (2005). Evolving Professions: An Institutional Field Approach. In Klatetzki, T., \& Tacke, V. (eds.), Organisation und Profession (pp. 119-142). Wiesbaden: VS Verlag.

Schimank, U. (2005). 'New Public Management' and the Academic Profession: Reflections on the German Situation. Minerva, 43(4), 361-376.

Schimank, U. (2010). Reputation statt Wahrheit: Verdrängt der Nebencode den Code? Soziale Systeme, 16(2), 233-242, DOI: https://doi.org/10.1515/sosys-2010-0204. 
Schmidt, D. (2005). Statistik und Staatlichkeit. Wiesbaden: Springer.

Schneijderberg, C. (2018). Promovieren in den Sozialwissenschaften. Eine sozialisationstheoretische Erschließung des Forschungsfeldes Promotion. Wiesbaden: VS Verlag.

Schubert, T, Frietsch, R., Rothengatter, O., et al. (2017). An analysis of the Excellence Initiative and its effects on the funded universities. Studien zum deutschen Innovationssystem Nr. 11-2017. Karlsruhe: Fraunhofer Institute for Systems and Innovation Research ISI.

Shin, J.C. (2009). Building World-class Research University: The Brain Korea 21 Project. Higher Education, 58(5), 669-688.

Shin, J.C., \& Cummings, W.K. (2010). Multilevel analysis of academic publishing across disciplines: Research preference, collaboration, and time on research. Scientometrics, 85(2), 581-594.

Shin, J.C., \& Lee, S.J. (2015). Evolution of research universities as a national research system in Korea: accomplishments and challenges. Higher Education, 70(2), 187-202. Shin, J.C., Kim, H., Park, H.Y., Shim, H.K., et al. (2009). Analysis on the factors of budget allocation to universities: evaluation-based funding mechanism. The Journal of Economics and Finance of Education, 18(4), 59-87.

Sivertsen, G. (2016). Patterns of internationalization and criteria for research assessment in the social sciences and humanities. Scientometrics, 107, 357-368.

Slaughter, S., \& Leslie, L.L. (1997). Academic Capitalism. Politics, Policies, and the Entrepreneurial University. Baltimore: Johns Hopkins University Press.

Smeby, J.-C., \& Try, S. (2005). Departmental Contexts and Faculty Research Activity in Norway. Research in Higher Education, 46(6), 593-619.

Snijders, T.A.B., \& Bosker, R.J. (2012). Multilevel analysis: An introduction to basic and advanced multilevel modeling (2nd edition). Los Angeles, London, New Delhi, Singapore, Washington DC: Sage.

Stata Corp (2015). Stata Statistical Software: Release 14. College Station: StataCorp LP. Stephan, P.E., \& Levin, S.G. (1992). Striking the mother lode in science: The importance of age, place, and time. New York: Oxford University Press.

Stichweh, R. (1994): Wissenschaft, Universität, Profession. Frankfurt a. M.: Suhrkamp. Stroebe, W. (2010). The graying of academia: will it reduce scientific productivity? The American Psychologist, 65(7), 660-673.

Teichler, U., Arimoto, A., Cummings, W.K., et al. (2013). The Changing Academic Profession. Major Findings of a Comparative Survey. Dordrecht: Springer. 
van Dalen, Hendrik P., \& Henkens, K. (2012). Intended and Unintended Consequences of a Publish-or-Perish Culture: A Worldwide Survey. Journal of the American Society for Information Science and Technology, 63(7), 1282-1293.

Van Leeuwen, T. (2006). The application of bibliometric analyses in the evaluation of social science research. Who benefits from it, and why it is still feasible. Scientometrics, 66(1), 133-154.

Vatin, F. (2013). Valuation as Evaluating and Valorizing. Valuation Studies, 1(1), 31-50. Volkmann, U., Schimank, U., Rost, M., et al. (2014). Two Worlds of Academic Publishing: Chemistry and German Sociology in Comparison. Minerva, 52(2), 187-212.

Vormbusch, U. (2012). Die Herrschaft der Zahlen. Zur Kalkulation des Sozialen in der kapitalistischen Moderne. Frankfurt a. M., New York: Campus.

Waaijer, C.J.F. (2015). The Coming of Age of the Academic Career: Differentiation and Professionalization of German Academic Positions from the 19th Century to the Present. Minerva, 53, 43-67.

Weingart, P. (2001). Die Stunde der Wahrheit? Zum Verhältnis der Wissenschaft zu Politik, Wirtschaft und Medien in der Wissensgesellschaft. Göttingen: Velbrück.

Weingart, P. (2005). Impact of bibliometrics upon the science system: Inadvertent consequences? Scientometrics, 62(1), 117-131.

Whitley, R. (2007). Changing Governance of the Public Sciences. In Whitley, R., \& Gläser, J. (eds.), The Changing Governance of the Sciences. Sociology of the Sciences Yearbook (pp. 3-27). Dordrecht: Springer.

Whitley, R. (2010). Introduction: Reconfiguring the Public Sciences: The Impact of Governance Changes on Authority and Innovation in Public Science Systems. In Whitley, R., Gläser, J., \& Engwall, L. (Eds.), Reconfiguring knowledge production. Changing authority relationships in the sciences and their consequences for intellectual innovation (pp. 3-57). Oxford: Oxford University Press.

Wilkesmann, U., \& Schmid, C.J. (2012). The impacts of new governance on teaching at German universities. Findings from a national survey in Germany. Higher Education, 63, 3352.

Wissenschaftszeitvertragsgesetz (2016). Gesetz über befristete Arbeitsverträge in der Wissenschaft (BGBI. I S. 442). Berlin.

Woelert, P. (2015). Governing Knowledge: The Formalization Dilemma in the Governance of the Public Sciences. Minerva, 53(1), 1-19.

Woelert, P., \& McKenzie, L. (2018). Follow the money? How Australian universities replicate national performance-based funding mechanisms. Research Evaluation, 27(3), 184-195. 


\section{Annex 1}

An example of MPR criteria at the very explicit end of the scale is the highly transparent listing by the Business, Management and Economics Department of the University of Göttingen. Publicly available on the website of the department are:

- $\quad$ MPR concept for research (Konzept LOM Forschung WiWi 2018) ${ }^{19}$

- MPR concept for teaching (Konzept LOM Lehre WiWi 2018)20

- Overview of journals by rank (Übersicht verfügbare Publikationsquellen WiWi mit Bewertungen (Stand: Juni 2018)) $)^{21}$

- Alphabetical list of journal metrics according to the Business and Management Association (Alphabetische Liste der Zeitschriftenbewertungen durch den Verband der Hochschullehrer der BWL (VHB-Liste: JOURQUAL 3.0) $)^{22}$

- List of journal metrics according to the German Economics Association 2008 (Liste der Zeitschriftenbewertung durch den Verein für Socialpolitik, Stand 2008 (VfS-Liste 2008) $)^{23}$

- List of journal metrics according to the German Economics Association 2011 (Liste der Zeitschriftenbewertung durch den Verein für Socialpolitik, Stand 2011 (VfS-Liste 2011) $)^{24}$

To facilitate the registration of publications in the MPR database the department also provides instructions for academics on how to create a new entry (Anlegen einer Publikation) ${ }^{25}$ and links to the user manual of FactScience ${ }^{26}$ guidelines for the evaluation of publications in FactScience $^{27}$.

19 https://www.uni-goettingen.de/de/konzept+lom+forschung+wiwi+2018/415683.html (last accessed 08 April 2020).

20 https://www.uni-goettingen.de/de/konzept+lom+lehre+wiwi+2018/415684.html (last accessed 08 April 2020). goettingen.de/de/\%c3\%9cbersicht+verf\%c3\%bcgbare+publikationsquellen+wiwi+mit+bewertungen+\% 28stand\%3a+juni+2018\%29/415686.html (last accessed 08 April 2020). goettingen.de/de/alphabetische+liste+der+zeitschriftenbewertungen+durch+den+verband+der+hochsc hullehrer+der+bwl+\%28vhb-liste\%3a+jourqual+3.0\%29/538660.html (last accessed 08 April 2020). 23

https://www.unigoettingen.de/de/liste+der+zeitschriftenbewertung+durch+den+verein+f\%c3\%bcr+socialpolitik\%2c+st and+2008+\%28vfs-liste+2008\%29/422725.html (last accessed 08 April 2020). goettingen.de/de/liste+der+zeitschriftenbewertung+durch+den+verein+f\%c3\%bcr+socialpolitik\%2c+st and $+2011+\% 28$ vfs-liste $+2011 \% 29 / 420848$.html (last accessed 08 April 2020).

$25 \mathrm{https}: / /$ www.uni-goettingen.de/de/anlegen+einer+publikation/415685.html (last accessed 08 April 2020).

26 https://www.uni-goettingen.de/de/benutzerhandbuch+factscience+/415687.html (last accessed 08 April 2020). 


\section{Annex 2}

Table A1, Annex 2: Relationship between Institutional Performance-based reward distribution and individually assessed research performance orientation of $\mathrm{HEI}$

\begin{tabular}{|c|c|c|c|}
\hline \multicolumn{4}{|c|}{$\begin{array}{l}\text { Dependent variable: institutional research } \\
\text { performance orientation (individually } \\
\text { assessed) }\end{array}$} \\
\hline \multicolumn{4}{|c|}{$\begin{array}{l}\text { Discipline (Ref: } \\
\text { natural sciences) }\end{array}$} \\
\hline & $\begin{array}{l}\text { Engineering } \\
\text { Social } \\
\text { sciences } \\
\text { Humanities } \\
\text { Economics }\end{array}$ & $\begin{array}{l}0.10 \\
0.16 \\
0.25\end{array}$ & $\begin{array}{l}0.10 \\
0.16 \\
0.25\end{array}$ \\
\hline \multirow[t]{3}{*}{ HEI } & $\begin{array}{l}\text { MPR } 1 \\
\text { MPR } 2 \\
\text { MPR } 3 \\
\text { Non-MPR } 1 \\
\text { Non-MPR } 2\end{array}$ & $\begin{array}{l}\text { (ref. Cat.) } \\
-0.02 \\
0.17 \\
-0.35 \\
-1.26^{\star * *}\end{array}$ & $\begin{array}{l}-0.17 \\
-0.19 \\
\text { (ref. Cat.) } \\
-0.52^{*} \\
-1.43^{* * *}\end{array}$ \\
\hline & Constant & $3.96^{\star \star \star}$ & $4.13^{\star \star \star}$ \\
\hline & $\mathrm{N}=$ & 305 & 305 \\
\hline
\end{tabular}


Table A2, Annex 2: Robustness check (of table 4): Institutional research performance orientation

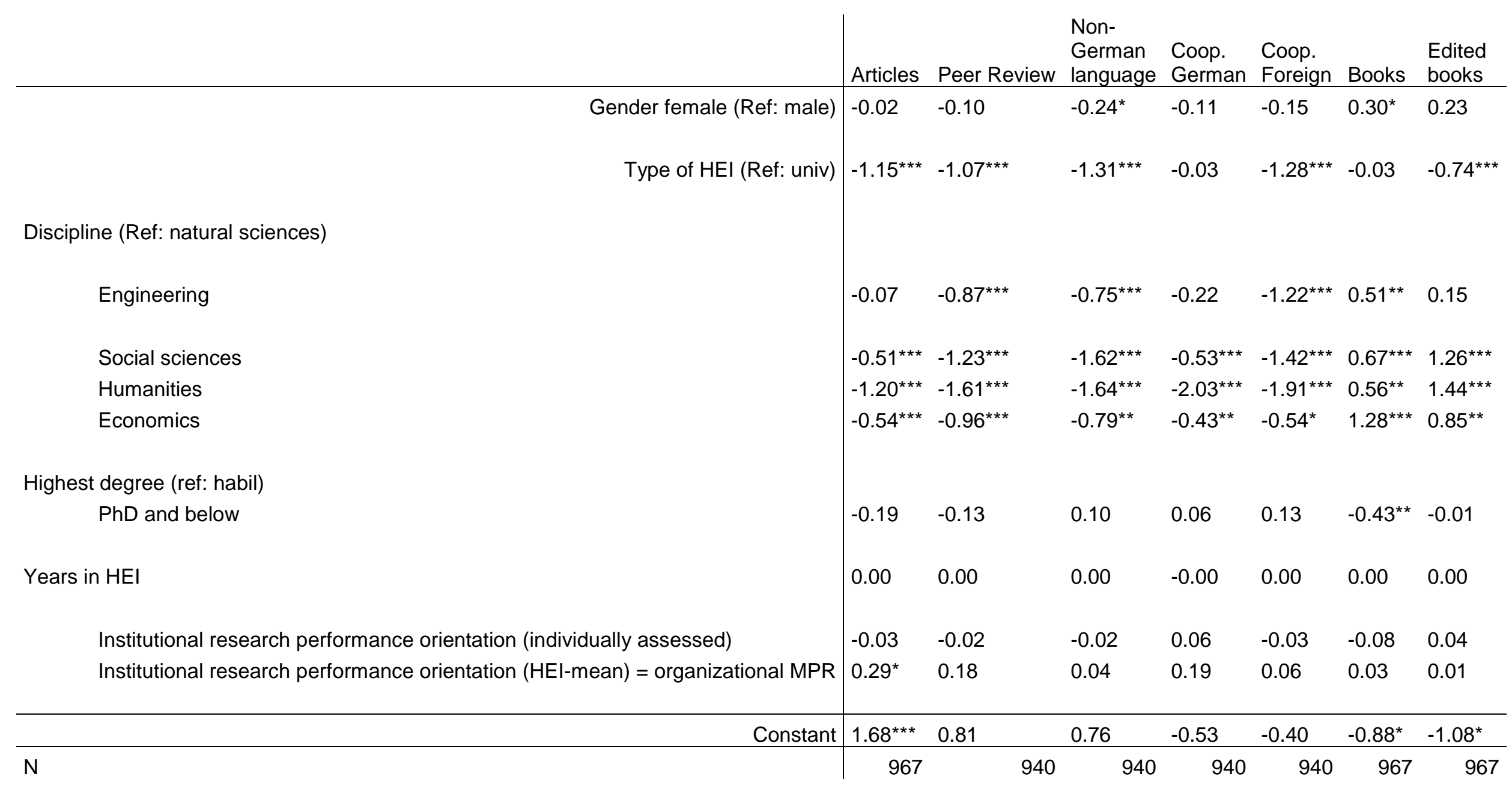

Negative binomial regression (Articles, Books), fractional regression models (Non-German language; Coop Foreign; Coop German; Peer Review); ${ }^{*} p<0.05,{ }^{* *} p<0.01,{ }^{* * *} p<0.001$. 
Table A3, Annex 2: Institutional research performance orientation by discipline

\begin{tabular}{|c|c|c|c|c|}
\hline & \multicolumn{2}{|c|}{ Articles } & \multicolumn{2}{|c|}{ Peer review } \\
\hline & $\begin{array}{l}\text { Natural } \\
\text { science } \\
\text { s }\end{array}$ & $\begin{array}{l}\text { Humanitie } \\
\mathrm{s}\end{array}$ & \begin{tabular}{|l} 
Natural \\
science \\
s
\end{tabular} & $\begin{array}{l}\text { Humanitie } \\
\mathrm{s}\end{array}$ \\
\hline Gender female (Ref: male) & 0.10 & -0.18 & -0.38 & 0.13 \\
\hline Type of HEI (Ref: univ) & $-0.87^{\star \star \star}$ & -0.30 & $-1.69^{\star \star \star}$ & -0.74 \\
\hline Highest degree (ref: habil) & & & & \\
\hline $\mathrm{PhD}$ and below & $-0.32^{*}$ & -0.22 & 0.05 & 0.19 \\
\hline Years in $\mathrm{HEI}$ & 0.00 & 0.00 & 0.00 & -0.00 \\
\hline $\begin{array}{l}\text { Institutional research performance } \\
\text { orientation }\end{array}$ & & & & \\
\hline $\begin{array}{l}\text { (individually assessed) } \\
\text { Institutional research performance }\end{array}$ & -0.03 & 0.05 & 0.12 & -0.08 \\
\hline (HEl-mean) & $0.60^{* \star *}$ & -0.18 & -0.21 & 0.47 \\
\hline Constant & 0.55 & $1.74^{*}$ & 1.82 & -1.79 \\
\hline $\mathrm{N}$ & 330 & 168 & 323 & 163 \\
\hline
\end{tabular}

Negative binomial regression (Articles), fractional logit model (Peer review); ${ }^{*} p<0.05,{ }^{* *} p<$ $0.01,{ }^{* * *} p<0.001$ 